\title{
Marked Calpastatin (CAST) Depletion in Alzheimer's Disease Accelerates Cytoskeleton Disruption and Neurodegeneration: Neuroprotection by CAST Overexpression
}

\author{
Mala V. Rao, ${ }^{1,2 \star}$ Panaiyur S. Mohan, ${ }^{1,2 \star}$ Corrinne M. Peterhoff, ${ }^{1}$ Dun-Sheng Yang, ${ }^{1,2}$ Stephen D. Schmidt, ${ }^{1}$ \\ Philip H. Stavrides, ${ }^{1}$ Jabbar Campbell, ${ }^{1}$ Yuanxin Chen, ${ }^{1}$ Ying Jiang, ${ }^{1}$ Peter A. Paskevich, ${ }^{5,6,7}$ Anne M. Cataldo, ${ }^{5,6,7}$ \\ Vahram Haroutunian, ${ }^{8}$ and Ralph A. Nixon ${ }^{1,2,3,4}$ \\ ${ }^{1}$ Center for Dementia Research, Nathan S. Kline Institute, Orangeburg, New York 10962, Departments of ${ }^{2}$ Psychiatry, ${ }^{3}$ Cell Biology, and ${ }^{4}$ Pathology, New \\ York University School of Medicine, New York, New York 10016, Departments of ${ }^{5}$ Psychiatry and ${ }^{6}$ Neuropathology and ${ }^{7}$ McLean Hospital, Harvard Medical \\ School, Belmont, Massachusetts 02478, and ${ }^{8}$ Department of Psychiatry, Mount Sinai School of Medicine, New York, New York 10029
}

Increased activity of calpains is implicated in synaptic dysfunction and neurodegeneration in Alzheimer's disease (AD). The molecular mechanisms responsible for increased calpain activity in AD are not known. Here, we demonstrate that disease progression is propelled by a marked depletion of the endogenous calpain inhibitor, calpastatin (CAST), from AD neurons, which is mediated by caspase-1, caspase-3, and calpains. Initial CAST depletion focally along dendrites coincides topographically with calpain II and ERK $1 / 2$ activation, tau cleavage by caspase-3, and tau and neurofilament hyperphosphorylation. These same changes, together with cytoskeletal proteolysis and neuronal cell death, accompany CAST depletion after intrahippocampal kainic acid administration to mice, and are substantially reduced in mice overexpressing human CAST. Moreover, CAST reduction by shRNA in neuronal cells causes calpain-mediated death at levels of calcium-induced injury that are sublethal to cells normally expressing CAST. Our results strongly support a novel hypothesis that CAST depletion by multiple abnormally activated proteases accelerates calpain dysregulation in AD leading to cytoskeleton disruption and neurodegeneration. CAST mimetics may, therefore, be neuroprotective in AD.

Key words: apoptosis; caspase; calpain; tau; cdk5; ERK

\section{Introduction}

Calpains are calcium-dependent neutral cysteine proteases, cleave cellular proteins and modulate signal transduction pathways that regulate cell shape, adhesion and migration, and neuronal functions, including synaptic plasticity ( $\mathrm{Wu}$ and Lynch, 2006). Calpains, composed of an $80 \mathrm{kDa}$ catalytic subunit and a $30 \mathrm{kDa}$ regulatory subunit, are classified as $\mu$-calpains (Cal I) or $\mathrm{m}$-calpains (Cal II), depending on the level of calcium required for their activation (Goll et al., 2003). Calpains are regulated by cytosol-to-membrane translocation, and by a calciumdependent heat-stable inhibitor, calpastatin (CAST) (Goll et al., 1992). Brain CAST is a $120 \mathrm{kDa}$ protein with four inhibitory

Received Aug. 28, 2008; accepted 0ct. 2, 2008.

This work was supported by the National Institute on Aging Grants (AG005604, P01AG002219), the National Institute of Neurological Disorders and Stroke Grant (NS P01NS048447), and the Mitsubishi Chemical Corporation. We are grateful to Nicole Piorkowski for assistance with manuscript preparation. We are thankful to Dr. Masatosh Maki (Nagoya University, Nagoya, Japan) for generously providing us with the CAST cDNA construct and Dr. Robert Siman for kindly providing Ab246 and Ab38 antibodies (University of Pennsylvania, Philadelphia, PA).

${ }^{*}$ M.V.R. and P.S.M. contributed equally to this work.

Correspondence should be addressed to Dr. Ralph A. Nixon, Nathan S. Kline Institute, 140 Old Orangeburg Road, Orangeburg, NY 10962. E-mail: Nixon@nki.rfmh.org.

DOI:10.1523/JNEUROSCI.4119-08.2008

Copyright $\odot 2008$ Society for Neuroscience $\quad$ 0270-6474/08/2812241-14\$15.00/0 domains liberated by calpain cleavage during the inhibitory process, releasing smaller fragments, ultimately inactivated by caspase proteolysis (Wang et al., 1998; Goll et al., 2003). Whether CAST tonically regulates calpain activity in neurons or buffers against pathological calpain activation is unresolved (Melloni et al., 2006).

Most calpain in neurons exists in latent form. Pathological activation of large stores of calpain during ischemia causes rapid cell death (Goll et al., 2003). Persistent calpain over-activation in injury or disease may stimulate signaling cascades involving cyclin-dependent kinase 5 (Cdk5) (Lee et al., 2000), extracellular regulated kinase (ERK) (Amadoro et al., 2006), glycogen synthase kinase 3 (GSK3) (Shiurba et al., 1996), or other kinases/phosphatases (Shea et al., 1996), all of which may lead to cytoskeleton hyperphosphorylation and either apoptosis or necrosis (Julien and Mushynski, 1998; Amadoro et al., 2006). Synthetic inhibitors of calpain exert varying levels of neuroprotection in animal and cellular models of brain injury, including ischemia, trauma, and excitotoxicity (Bartus et al., 1995). The precise contribution of calpain inhibition to neuroprotection remains unclear because these inhibitors modulate other cysteine or serine proteases that influence neurodegenerative processes in unknown ways (Carragher, 2006). 
Abnormal calpain activation is observed early in AD (Saito et al., 1993) and disturbances in calcium homeostasis related, in part, to excitotoxicity, $\beta$-amyloid neurotoxicity, and free radical injury, are considered to be factors in $\mathrm{AD}$ pathogenesis (Lee et al., 2000; Law et al., 2001). Cal I activation is observed well before neurons degenerate, implying that neurons tolerate some degree of calpain activation, which mediates repair and survival responses and modulates synaptic plasticity (Battaglia et al., 2003; Wu and Lynch, 2006). Hyperactivation of Cal II is associated with translocation of activated calpain to tau aggregates, extensive neurofibrillary degeneration, and neuronal loss in $\mathrm{AD}$ (Grynspan et al., 1997b; Adamec et al., 2002).

In this study, we established CAST as a regulator of constitutive calpain activity in neurons in vivo and as a neuroprotectant against pathological activation of calpain in $\mathrm{AD}$ and kainate neurotoxicity. We observed marked CAST depletion in the brain as $\mathrm{AD}$ advances, and implicate caspase-1, caspase- 3 and calpains in the underlying mechanisms. We further demonstrate in $\mathrm{AD}$ brain, transgenic mice, and cell models that depletion of CAST accelerates a cascade involving calpain-mediated activation of specific protein kinases and cytoskeleton disruption, leading ultimately to cell death. Blocking CAST depletion substantially prevents this cascade indicating the potential neuroprotective value of selective calpain inhibitors in $\mathrm{AD}$ and excitotoxic-related injury.

\section{Materials and Methods}

Human brain tissues and analysis. Fixed and frozen postmortem brains from early stage (Braak stage III, $n=9$ ), moderate to severe AD (Braak stage V, $n=15$; Braak stage VI, $n=20$ ), and age-matched, postmortem interval matched neurologically normal control $(n=20)$ cases were obtained from the Harvard Brain Tissue Resource Center (McLean Hospital, Belmont, MA) (Table 1). Tissues were also obtained from a series of 79 brains of both sexes ranging in age from 62 to 103 years from Drs. Vahram Haroutunian and Daniel P. Perl, Bronx VA Medical Center, Bronx NY, and Mt. Sinai Medical Center, New York, NY (Parvathy et al., 2001) (Table 2). These cases were part of an AD study cohort consisting of subjects that had been classified antemortem on the basis of clinical dementia rating (CDR) scores as either cognitively intact (CDR 0 ), questionably demented (CDR 0.5), mildly impaired (CDR 1), moderately impaired (CDR 2) or severely demented (CDR 5). The subject's age at death, cognitive status, and other clinical information were used to arrive at a final clinical diagnosis.

Production of human CAST transgenic mice. Human CAST (hCAST) construct (Hitomi et al., 1998) was cloned into a Thymocyte differentiation antigen 1.1 (Thy1.1)-expression cassette. Thy1.1-hCAST construct was digested with EcoRI and NdeI (Hitomi et al., 1998) and fractionated on $0.7 \%$ SeaPlaqueGTG-agarose gels. Thyl.1-hCAST transgene fragment $(9.4 \mathrm{~kb})$ was gel purified by electroelution, phenol chloroform extraction, dialyzed with 3 changes of TE $(10 \mathrm{~mm}$ Tris- $\mathrm{HCl}, \mathrm{pH} 7.5$ and 1 mM EDTA) in a collodion bag (Sartorius) at $4^{\circ} \mathrm{C}$, filtered through 0.22 $\mu \mathrm{m}$ filter (Millex-GV4, Millipore), ethanol precipitated, and dissolved in DNA injection buffer ( 5 mm Tris-HCl, $\mathrm{pH} 8.0$ and $0.1 \mathrm{~mm}$ EDTA). DNA was injected into FVBN embryos at New York University School of Medicine transgenic mouse facility, and founders were identified by Southern blotting. hCAST-expressing founders were bred with C57BL/6J mice to produce hCAST transgenic lines. The mice used in these studies were $4-5$ months old.

Injection of kainic acid into hippocampus. A 32-gauge needle of $0.5 \mu \mathrm{l}$ syringe mounted on a Reproducibility Adapter (Hamilton) was inserted into the dorsal hippocampus $[-2.3 \mathrm{~mm}$ anterior-posterior (AP), -2 mm medial-lateral (ML), and $1.8 \mathrm{~mm}$ dorsal-ventral (DV) of male mice] using bregma as a reference for AP and ML coordinates and the skull as a reference for DV coordinates (Franklin and Paxinos, 1997). Kainic acid (KA) solution $(0.5 \mathrm{nmol} / \mu \mathrm{l})$ was injected $(0.2 \mu \mathrm{l})$ at a constant flow rate over $1 \mathrm{~min}$. To prevent reflux of the injected solution along the needle track, the needle was held in a stationary position for an additional $2 \mathrm{~min}$, then raised twice in $0.5 \mathrm{~mm}$ increments with a $1 \mathrm{~min}$ interval before the needle was completely removed. In each experiment, at least one mouse was injected with Evans blue using the same stereotaxic coordinates to confirm the exact delivery site of the injections. Seven days after single injection, mice were either perfused with $4 \%$ paraformaldehyde for immunocytochemistry (ICC) ( $n=3-4$ for each genotype) or total homogenates were made from hippocampus and analyzed by Western blotting ( $n=5$ mice for each genotype).

Cell culture. SH-SY5Y human neuroblastoma cells (ATCC) were subjected to various treatments or transfected with CAST shRNA $(0.5 \mu \mathrm{g}$; TransIT-LT1, Mirus Bio Corporation) reagent according to the manufacturer's instructions. After $24 \mathrm{~h}$ the medium was replaced with fresh medium. Cell viability was monitored for $2-3 \mathrm{~d}$ and the cells were immunostained with antibodies according to Cataldo et al. (1990). The images were captured on a Zeiss Axiovert 200M microscope equipped with Axiocam $\mathrm{mRm}$ digital camera (Carl Zeiss). Cells were counted using BioQuant Nova software version 5.508 (Bioquant).

CAST shRNA construct and transformations. The siRNA sequence of CAST 5'-AAGCCGGGTGACAAGAAAAAA-3' was used to construct shRNA plasmid. Briefly, complementary 60 bp polynucleotides, which contain a loop, head to head $21 \mathrm{bp}$ siRNA and ACC 65 I site at $5^{\prime}$ and ClaI at $3^{\prime}$ end were synthesized by Qiagen (GGTACCAAGCCGGGTGACAAGAAAAAATCTTCTTTTTTTCTTGTCACCCGGCTTATCGATA). The complementary oligonucleotides were annealed and $5^{\prime}$ phosphorylated with T4 PNK and inserted into shRNA vector (siGFP contains an eGFP marker, a Zeocin resistance gene, an H1RNA promoter and LacZ for blue/white selection) by T4 DNA ligase. The ligated DNA was transformed into One Shot Stbl3 chemically competent cells (Invitrogen) and Zeocin resistant colonies were screened with $C l a I$ enzyme to identify CAST-shRNA clones, Endo-toxin free DNA (Qiagen) was made, transfected into SH-SY5Y cells, and pcDNA3.1 vector was used as a control.

Antibodies. Commercial antibodies were obtained from the following sources: polyclonal antibody (pAb) caspase-1 (C-20), pAb Cdk5, pAb p35 (C-19), monoclonal antibody (mAb) tauC3 (Santa Cruz Biotechnology); pAb phosphorylation independent ERK1/2, pAb GSK3 $\beta$ (ser9), and pAb p35 (Cell Signaling Technology); pAb GSK $3 \alpha / \beta$ (pY279/216), p-ERK (thr202/204), and mAb total tau T46 (Invitrogen); mAb $\alpha$-spectrin and mAb Neu N (Millipore); pAb GFAP and mAb tubulin (Sigma). Additional antibodies prepared in our laboratory include the following: pAb C-18/C-24 (Saito et al., 1993); sheep pAb I-2-7 (Grynspan et al., 1997b); mAb NF-L 21.4, MAP-2 and hCAST 3.1 (see below). Polyclonal Ab38 (calpain-cleaved $\alpha$-spectrin) and Ab246 (caspase-cleaved $\alpha$-spectrin) were the kind gifts of Dr. Robert Siman, University of Pennsylvania, Philadelphia, PA. Monoclonal tau antibodies AT-8 (Pierce) and 
PHF-1 were generously provided by Dr. Peter Davies, Albert Einstein School of Medicine, Bronx, NY.

Production of monoclonal NF-L (21.4) and MAP-2 antibody (18.1). $\mathrm{BALB} / \mathrm{c}$ mice were immunized with bovine spinal cord cytoskeletal preparations. Activated splenocytes were fused with SP2/0 cells, selected and grown. The cells producing the antibody toward NF-L and MAP-2 were expanded and ascites fluids with high titers were generated. These antibodies recognize only their specific antigens.

Production of monoclonal antibody to hCAST (3.1). Recombinant hCAST domain 1 (Takara Biochemicals) was used as an immunogen to raise $3.1 \mathrm{mAb}$, as described above. The specificity of this $\mathrm{mAb}$ was tested on purified human CAST by Western blots and ICC of human brain.

Production of polyclonal Cal I antibodies. Mouse Cal I peptide $\left(\mathrm{NH}_{2}-\right.$ C-DVVIDDLLPTKDGKLVFV-COOH) corresponding to amino acids 161-178 was synthesized and injected into rabbits. After initial boost, antiserum was tested on mouse brain extracts, recombinant Cal I and purified Cal II. The antibody detects $80 \mathrm{kDa}$ calpain from mouse brain and recombinant $\mathrm{Cal} \mathrm{I}$ but not $\mathrm{Cal}$ II on immunoblots.

Immunocytochemistry. Mice were fixed by transcardiac perfusion of $4 \%$ paraformaldehyde in $0.1 \mathrm{M} \mathrm{Na}_{2} \mathrm{HPO}_{4}-\mathrm{NaH}_{2} \mathrm{PO}_{4}$, $\mathrm{pH} 7.5$ buffer, delivered with a peristaltic pump at $20 \mathrm{ml} / \mathrm{min}$ for $5 \mathrm{~min}$. Brains were removed and postfixed overnight in the same solution. Sections $(40 \mu \mathrm{m})$ of fixed human or mouse tissue were immunostained as described previously (Cataldo et al., 1990) using the Avidin-biotin (ABC) kit (Vector Laboratories) with diaminobenzidine tetrahydrochloride as the chromogen. For fluorescence immunohistochemistry, secondary antibodies conjugated with Alexa Fluors 488 and 568 (Invitrogen) were used.

Morphometric analyses. Sections from prefrontal cortices of $5 \mathrm{AD}$ and 5 age-matched control brains were analyzed semiquantitatively by densitometric analyses. Sections were immunolabeled with I-2-7 antibody using the $\mathrm{ABC}$ technique, coded and analyzed blindly. The immunolabeled cortices were visualized under a microscope equipped with a Dege solid-state digital camera and Bioquant image analysis software (R and M Biometrics). Using a $100 \times$ oil-immersion objective (nA 1.518), a total of 25 small, medium and large neurons with visibly defined nuclei were selected at random for each cortical lamina. The perimeter of the neuron was traced and the area (in square micrometers) recorded. A second tracing outlining the perimeter of the nucleus was made and this area was subtracted. The average optical density representing the total area of the neuron was recorded on a scale of $0-255$ ( 0 , lowest density; 255 , highest density). For each image filed, an image box was placed in the background region and the optical density recorded. A second set of $5 \mathrm{AD}$ and 5 age-matched controls were run to confirm the results. Statistical computations were performed using Student's $t$ test.

SDS-PAGE and Western blotting. SDS-PAGE followed by Western blotting was performed according to Mohan and Nixon (1995). The immunoreactive bands were visualized with ECL reagent (Amersham), and the bands were quantified using MultiGauge software (Fuji film).

Preparation of tissue extracts. Cerebral cortex from human brain $(0.5 \mathrm{~g})$ was homogenized as described previously (Schmidt et al., 2005) (but without leupeptin, antipain, and EGTA in samples subsequently used for caspase-1 and Cal II digestions), supernatants were boiled to inactivate endogenous calpain and heat stable CAST was recovered by centrifugation in supernatants. Mouse tissues were homogenized in a buffer (50 mM Tris- $\mathrm{HCl}, \mathrm{pH} 8.0,150 \mathrm{~mm} \mathrm{NaCl}, 50$ EDTA, $1 \%$ glycerol, $1 \mathrm{~mm}$ $\beta$-glycerophosphate, $1 \mathrm{~mm} \mathrm{NaF}, 0.2 \mathrm{~mm} \mathrm{NaVaO}_{4}$ and $0.1 \mathrm{~mm} \mathrm{PMSF}$ ) and centrifuged at $14,000 \times g$ for $20^{\prime}$ at $4^{\circ} \mathrm{C}$. Clear supernatants were assayed for protein content by the BCA method.

Calpastatin assay. CAST activity was expressed as the degree to which Cal II activity is decreased. Cal II was partially purified from postmortem human brain as described previously (Vitto and Nixon, 1986), and Cal II activity was measured with ${ }^{14} \mathrm{C}$-azocasein as substrate, which was prepared by reductive alkylation using ${ }^{14} \mathrm{C}$-formaldehyde (Dottavio-Martin and Ravel, 1978). Multiple volumes of cytosolic and membrane fractions were incubated for $10 \mathrm{~min}$ at $4^{\circ} \mathrm{C}$ with the Cal II $(0.3 \mu \mathrm{g})$ and the enzyme reaction was started at $30^{\circ} \mathrm{C}$ by adding ${ }^{14} \mathrm{C}$-azocasein to a final concentration of $0.025 \%$ in a reaction mixture containing $50 \mathrm{~mm}$ Tris- $\mathrm{HCl}, \mathrm{pH}$ 7.4, $1 \mathrm{~mm}$ DTT and $2 \mathrm{~mm} \mathrm{CaCl}_{2}$ for $30 \mathrm{~min}$ and was terminated by adding $10 \%$ TCA. Enzyme activity was measured as the percentage radioactivity in the acid soluble fraction after centrifugation. Inhibitory activity was expressed as $\mathrm{U} / \mathrm{ml}$. One unit was defined as the amount of inhibitor required to inhibit $50 \%$ activity of $0.3 \mu \mathrm{g}$ of Cal II.

Caspase-1 and Cal II digestion of human brain extracts. Caspase-1 digestion was performed according to Thornberry (1994). Briefly, $45 \mu \mathrm{g}$ of protein from CAST-enriched heat stable supernatants of control human brains were digested in a reaction buffer containing 50 mM HEPES pH 7.4, $100 \mathrm{~mm} \mathrm{NaCl}, 1 \mathrm{~mm}$ EDTA, 10\% glycerol, 0.2\% CHAPS, $10 \mathrm{~mm}$ DTT) and 1-5 $\mu \mathrm{l}(0.7-3.3 \mu \mathrm{M})$ of recombinant caspase-1 (Calbiochem) at $37^{\circ} \mathrm{C}$ for $2.5 \mathrm{~h}$. Cal II digestion (Vitto and Nixon, 1986) of heat stable supernatants ( $45 \mu \mathrm{g}$ of protein) was performed with $2 \mu \mathrm{g}$ of purified Cal II from human brain (70,000 units/mg) and $5 \mathrm{mM} \mathrm{CaCl}_{2}$ at $30^{\circ} \mathrm{C}$ for 20 $\mathrm{min}$. The enzyme reaction was stopped by boiling for $5 \mathrm{~min}$ followed by centrifugation at $13,000 \times g$ for $10^{\prime}$ at $4^{\circ} \mathrm{C}$ and supernatants were immunoblotted with CAST antibody (I-2-7).

Calpain activation experiments. Calpain activation was performed in SH-SY5Y cells by incubating with $5 \mu \mathrm{M}$ ionomycin and $5 \mathrm{mM} \mathrm{CaCl}_{2}$ for $2 \mathrm{~h}$ at $37^{\circ} \mathrm{C}$. The cells were washed with Hank's balanced salt solution, fixed and used for ICC.

All of the human and animal studies conducted in the study are approved and in compliance with the Nathan Kline Institute human IRB and IACUC. We confirm that informed consent was obtained from all human subjects.

\section{Results}

\section{Calpastatin distribution in normal human brain}

Western blot analysis with an affinity-purified sheep antiserum directed against human CAST (I-2-7) detected the major band of $110-120 \mathrm{kDa}$ CAST (Mohan and Nixon, 1995) in human SHSY5Y neuroblastoma cells (Fig. $1 A$, top, lane 1 ), human brain (Fig. $1 A$, top, lane 2), and mouse brain (Fig. $1 A$, top, lane 3 ). A human-specific monoclonal CAST antibody (CAST 3.1) recognized a similar $\sim 110-120 \mathrm{kDa}$ band in SH-SY5Y cells and human brain (Fig. $1 A$, bottom, lanes 1 and 2 ) which was not detected in mouse brain. Minor bands at $\sim 70$ and $41 \mathrm{kDa}$ (Fig. $1 A$, top, lane 2) are CAST cleavage products generated by calpain (Grynspan et al., 1997a). In immunocytochemical analyses, the I-2-7 antibody prominently labeled the long dendritic arborizations of neurons throughout different regions of human brain, including the pyramidal neurons in laminas IV and V of frontal cortex (Fig. 1 B1), hippocampal pyramids (Fig. 1B2), and cerebellar Purkinje cells (Fig. 1 B3), whereas glial cells stained relatively weakly. The distribution of CAST (Fig. 1C1) closely resembled that of Cal II (C-24 antibody) (Fig. 1C2).

Calpastatin is markedly depleted from dendrites in $\mathrm{AD}$ brain We observed strong neuronal CAST immunolabeling in the cortices of control brains (Fig. 1D1,E1) contrasting with markedly reduced immunolabeling observed in these regions of $\mathrm{AD}$ cases (Fig. 1D2,E2). CAST immunoreactivity was particularly depleted along dendrites of layer III (Fig. 1E2) and layer V (data not shown) pyramidal neurons, but was relatively preserved in dendrites of neurons in layer VI of prefrontal neocortex (compare Fig. $1 F 1$ and F2). Semiquantitative analyses of the laminar distribution of CAST immunoreactivity in frontal cortex from latestage $\mathrm{AD}$ brains $(n=5)$ and age- and postmortem-interval (PMI)-matched controls $(n=5)$ under identical conditions indicated that CAST levels in $\mathrm{AD}$ brains were markedly reduced in layers I, II and III to $40 \pm 11 \%, 44 \pm 14 \%$ and $34 \pm 8 \%$, respectively compared with controls ( $p<0.01$ for all comparisons), moderately lowered in layers IV-V to $57 \pm 17 \%$ and $44 \pm 16 \%$, respectively ( $p<0.05$ for all comparisons), but not significantly affected in layer VI $(70 \pm 15 \%)$ (Fig. $1 G)$. Another set of $5 \mathrm{AD}$ and 5 control brains yielded the same results (data not shown).

CAST depletion was further confirmed by quantitative immu- 

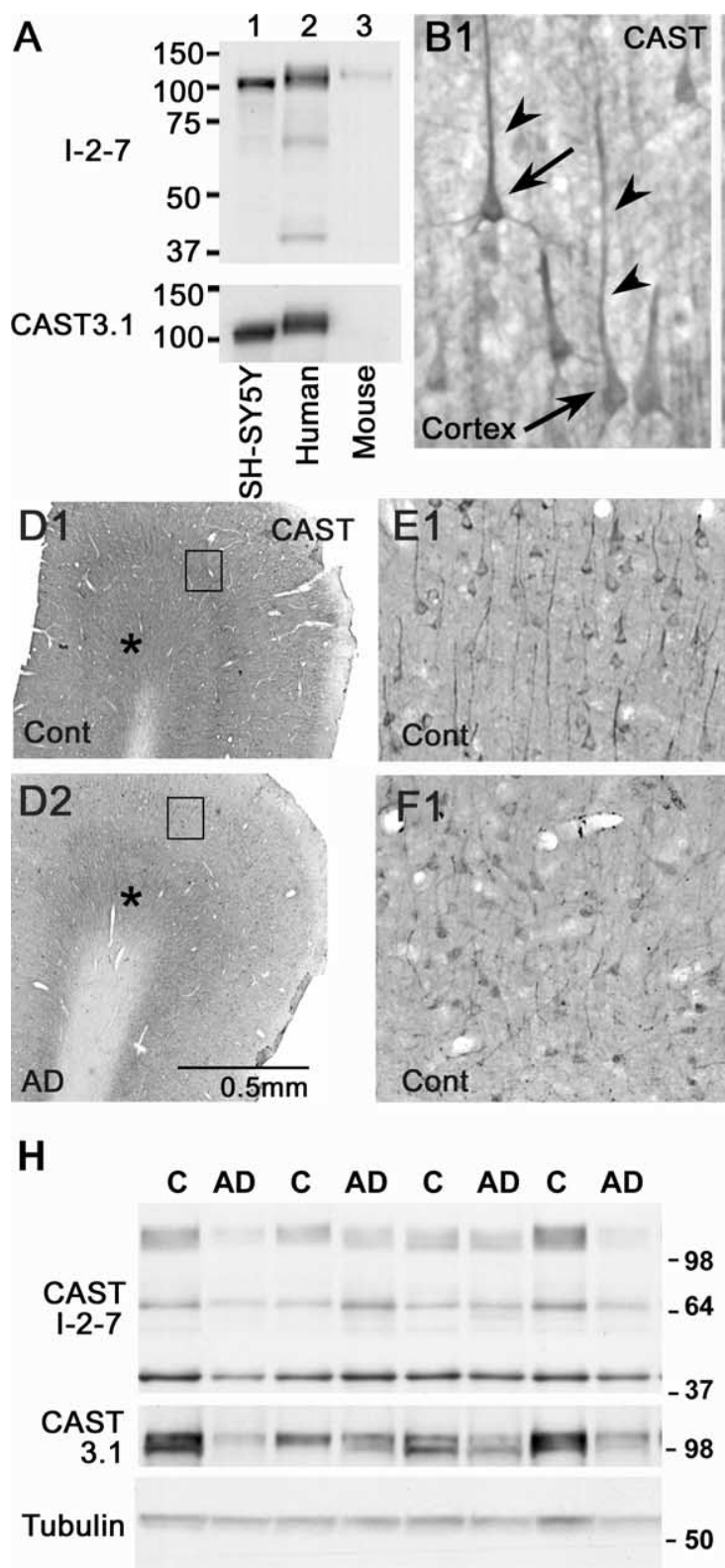
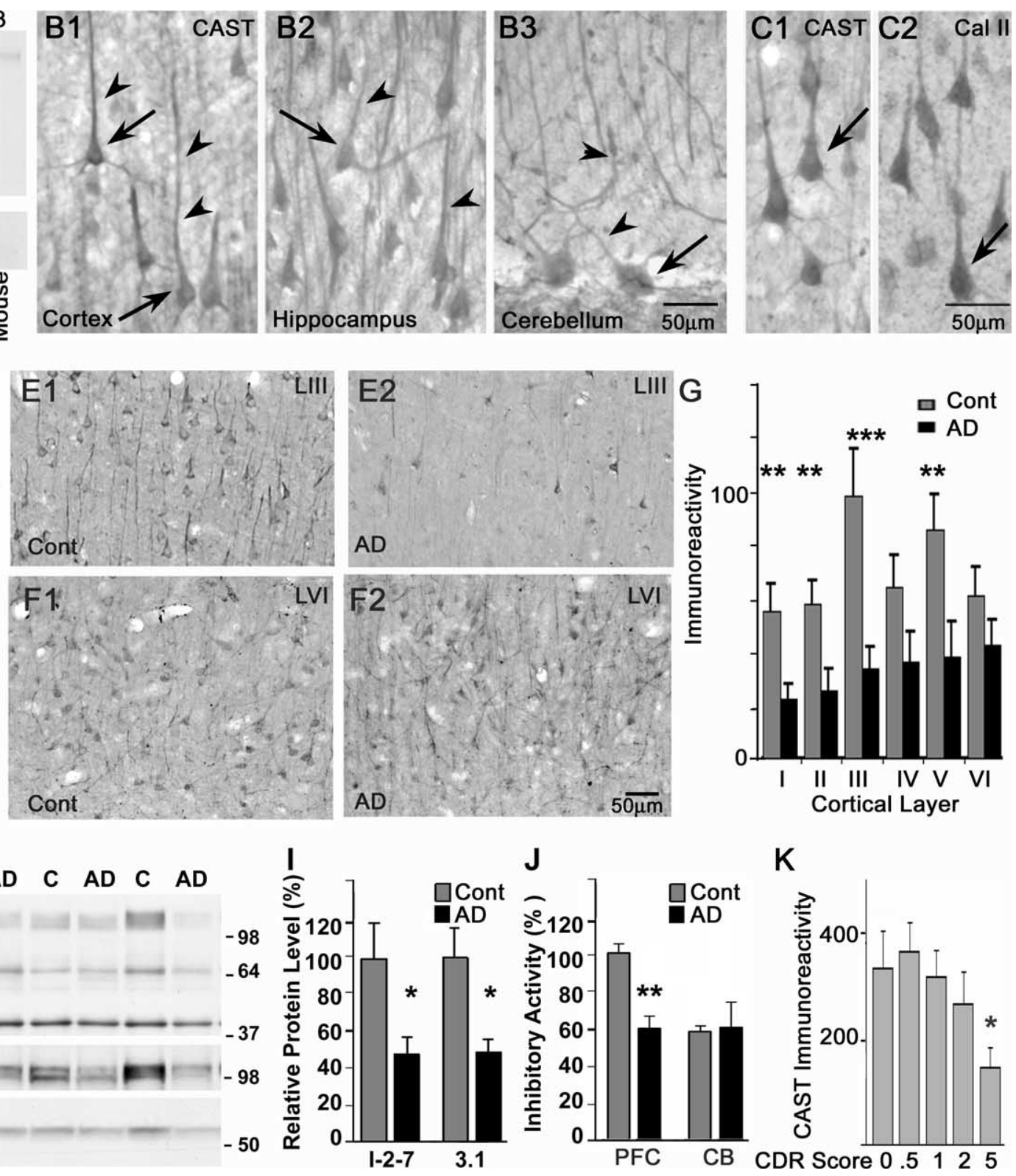

Figure 1. CAST is depleted in prefrontal cortex (layers I-V) of AD brains. A, Cytosolic extracts from SH-SY5Y cells, homogenates of human and mouse brains were immunoblotted with two different CAST antibodies (I-2-7, top or CAST 3.1, bottom), revealing an immunoreactive band of 110-120 kDa corresponding to human CAST. $\boldsymbol{B}$, In human control brain, CAST immunoreactivity (I-2-7) is localized predominantly within the soma (B1-B3, long arrows) and dendrites (B1-B3, arrowheads) of neurons in the frontal cortex, hippocampus, and cerebellum. $C$, An antibody to activated Cal II (C-24) (C2, arrows) immunolabeled neuronal populations in the same brain regions as CAST in a similar pattern (C1, arrows). In AD brain (D2, E2), CAST immunocytochemistry revealed a differential loss of immunoreactivity within several lamina of the cortical mantle compared with normal controls (D1, E1). In AD brains, reduction of CAST immunolabeling was most prominent in lamina III (D2, box; E2), whereas loss of CAST immunoreactivity was not detected in layer VI (asterisk, D2, F2). G, Densitometric analysis of brain sections immunostained for CAST under identical conditions show marked CAST reductions in $\mathrm{AD}(n=5)$ in prefrontal neocortex layers $\mathrm{I}-\mathrm{V}(p<0.01)$ but not in layer VI compared with control $(n=5)$ brains. ${ }^{* * *} p<0.01$. $I$, Quantitative immunoblots indicate the levels of full-length CAST and its cleaved fragments revealed with I-2-7 and 3.1 antibodies are reduced in AD neocortex $(\boldsymbol{H}, \boldsymbol{I})\left(n=5 ;{ }^{*} p<0.05\right)$ compared with controls $(n=6)$. CAST inhibitory activity against calpain was also significantly reduced in prefrontal cortex (PFC) $(J)\left(^{* *} p<0.01\right)$ but not in cerebellum (CB) $(J)$. In cases of AD subclassified by CDR scores ranging from 0 to 5 , we found that CAST immunoreactivity declined as the severity of clinical dementia increased $(\boldsymbol{K})$. Partial correlation coefficient between the CAST content and CDR score was $r=$ $-0.345(p<0.003)$ after controlling for age and PMI. C and Cont, Control.

noblot analyses of brains from individuals with moderate $\mathrm{AD}$ (Braak stage V) and normal controls. CAST levels (full-length) were markedly lower in cortex from $\mathrm{AD}$ brains compared with controls (Fig. $1 H$ ). In analyses of $\mathrm{AD}$ and control brains, total CAST levels were significantly lowered in prefrontal cortex (by I-2-7: $53 \pm 10 \%$; by CAST 3.1: $52 \pm 8 \%$; $p<0.05$ for both comparisons; $n=6$ for control cases, $n=5$ for AD cases) (Fig. $1 I$ ) and were paralleled by reductions in CAST inhibitory activity assayed in vitro (Fig. $1 J)(p<0.0001)$. In contrast, CAST inhib- itory activity was unaltered in the $\mathrm{AD}$ cerebellum, a brain region with minimal vulnerability to neurodegeneration (Fig. $1 \mathrm{~J}$ ).

CAST depletion from brain was progressive as $\mathrm{AD}$ advanced. A cohort of 79 individuals (Table 2) evaluated cognitively within a year of death was stratified into 5 groups based on their CDR scores $(0,0.5,1,2$, and 5). Quantitative immunoblot analyses of prefrontal neocortex samples from these groups revealed that total CAST levels were lowered beginning at the CDR 2 stage (22\%) and were markedly lowered (59\%) in the CDR 5 group 
(Fig. $1 K)(p<0.02)$. A univariate analysis of covariance (ANCOVA) was performed with CAST content as the dependent variable, age, gender, and PMI as covariates, and CDR scores as fixed factors. This resulted in an $F$ value of 3.119 (df: 4 and 65) and $p<0.021$, indicating that classification of data based on the CDR scores explained the variation in CAST content after controlling for age, gender, and PMI. Post hoc pairwise comparisons showed statistically significant decreases in CAST content with increasing CDR score. Partial correlation coefficient between the CAST content and CDR score was $r=-0.345, p<0.003$ after controlling for age and PMI (data not shown).

\section{Calpastatin depletion is mediated by both caspase and calpain activation}

In $\mathrm{AD}$ brain tissue, an antibody directed against the active site of Cal II (C-18) (Grynspan et al., 1997b) was used to label sections of frontal cortex from brains analyzed in Figure $1 \mathrm{~K}$ ranging from CDR 0 to CDR 5. Concomitant with the loss of CAST in Figure $1 \mathrm{~K}$, immunoreactivity for Cal II increased at the CDR 2 stage and was strong throughout the frontal cortex in CDR 5 cases (Fig. $2 A$ ). Double label immunofluorescence studies with the C-18 and I-2-7 antibodies on sections from the early stage AD cases (Braak stage III) revealed that the appearance of activated Cal II immunoreactivity correlated with reduced CAST immunolabeling (Fig. $2 \mathrm{~B}$, arrowheads). CAST immunolabeling was absent in neurofibrillary tangles, which were intensely Cal II positive (Fig. $2 \mathrm{~B}$ ). Within individual neurites, the loss of CAST immunoreactivity in a given segment of the process (Fig. $2 C$, arrowheads) coincided with prominent Cal II immunoreactivity (Fig. 2C, arrows). Portions of neurites that were immunopositive for activated Cal II were usually also labeled by the antibodies AT8 (Fig. 2D) and PHF1 (Fig. 2E), which recognize tau phospho-variants associated with straight and paired helical filaments. Because Cal II activation was undetectable in control human brains with either C-18 or C-24 antibody, double immunolabeling for Cal II and CAST was not demonstrated.

We have previously implicated calpain-dependent ERK activation in the hyperphosphorylation of cytoskeletal proteins in AD brain (Veeranna et al., 2004). Cdk5 and GSK3 are also involved in tau hyperphosphorylation (Shiurba et al., 1996; Cruz et al., 2003; Plattner et al., 2006), which prompted us to investigate the distribution of these kinases in $\mathrm{AD}$. Double-immunolabeling with antibodies against CAST and p35/25 (supplemental Fig. $1 A$, available at www.jneurosci.org as supplemental material), detected no relationship between CAST depletion and altered abundance of p35/25 in neurites of perikarya, although currently available antibodies (C-19), which recognize both p35 and p25, cannot distinguish a possible conversion of p 35 to p 25 by immunocytochemistry. These results are consistent with additional quantitative Western blot analyses showing that total levels of cdk5 and the ratio of p35 to p25 in prefrontal cortex were not significantly different between $\mathrm{AD}(n=11)$ and control $(n=11)$ brains (supplemental Fig. $1 B$, available at www.jneurosci.org as supplemental material). Levels of p25 were modestly reduced $30 \%(p<0.05)$, in accordance with most previous analyses (Takashima et al., 2001; Taniguchi et al., 2001; Yoo and Lubec, 2001; Tandon et al., 2003; Cole et al., 2007). Additional doubleimmunofluorescence labeling with antibodies against the activated form of GSK3 (pY276 $\alpha / \mathrm{pY} 216 \beta$ ) in control and AD brains, show that activated GSK3 was barely detected in dendrites of AD brains as reported previously (Shiurba et al., 1996), and its abundance in neuronal perikarya did not vary in neurons that were either strongly or weakly labeled by CAST antibodies (supple- mental Fig. $1 C$, available at www.jneurosci.org as supplemental material). These results were consistent with measurements showing that the ratios of active to total GSK3 $\beta$ (supplemental Fig. $1 D$, available at www.jneurosci.org as supplemental material) and inactive to total GSK3 $\beta$ (supplemental Fig. $1 D$, available at www.jneurosci.org as supplemental material) were not significantly different in lysates from $\mathrm{AD}$ and control cortex.

Neuritic segments exhibiting calpain activation and CAST depletion were intensely immunopositive with an antibody against a cleavage product of tau, TauC3, in $\mathrm{AD}$ brain (Gamblin et al., 2003) (Fig. 3A). This cleavage is generated by caspase-3, a protease known to degrade CAST (Wang et al., 1998). Western blot analysis of CAST breakdown products in brain homogenates revealed a mean 2.5 -fold increase in a $30 \mathrm{kDa}$ band in $\mathrm{AD}$ cases that was almost imperceptible in controls (Fig. $3 B$, arrow) $(p<0.05)$. In addition, we observed mean increases of 43,72 , and $57 \%$ in CAST-immunoreactive bands at 28,25 , and $20 \mathrm{kDa}$, respectively, in $\mathrm{AD}$ cases compared with controls (Fig. $3 B$ ). Mean band intensity of the $30,28,25$ and $20 \mathrm{kDa}$ bands to corresponding $110 \mathrm{kDa}$ bands were significantly higher in $\mathrm{AD}$ versus control cases (data not shown; $n=6$ for control cases, $n=5$ for AD cases). Heat stable CAST-enriched from control brains incubated with caspase-1, a caspase known to be activated early in AD and upregulated in expression as AD progresses (Zhu et al., 1999; Pompl et al., 2003), generated increasing levels of the $30 \mathrm{kDa}$ band (Fig. $3 C$, arrow) in a time and concentration-dependent manner, and reduced the levels of CAST holoprotein and calpain-cleaved 70 and $41 \mathrm{kDa}$ CAST breakdown products (Fig. 3C) that retain calpain-inhibitory activity. In contrast, incubation of CAST extracts with partially purified Cal II yielded increased levels of the 28, 25, and $20 \mathrm{kDa}$ CAST fragments elevated in AD brains (Fig. $3 D$ ). Densitometric analyses of immunoblots probed with an antibody to caspase- 1 detected a $10 \mathrm{kDa}$ activated form of caspase-1, which was increased $>3$-fold in $\mathrm{AD}$ brains (Fig. $3 E$ ) compared with controls $(p<0.05 ; n=6$ for controls and $n=5$ for AD cases).

\section{Calpastatin overexpression in neurons of transgenic mice modulates constitutive calpain-mediated proteolysis in vivo} To investigate how CAST levels influence neuronal vulnerability in vivo, we produced hCAST mice under the Thy-1.1 promoter containing expression cassette (Fig. $4 A$ ). Southern blot analysis of tail DNAs identified founders (Fig. $4 B$ ) and 5 hCAST lines were established by crossing founders to C57BL/6J mice. Immunoblot analyses of total brain extracts from the founder lines and littermate controls (Ntg) with the CAST antibodies I-2-7 (reactive with mouse and human) and CAST 3.1 (human-specific) showed that lines 5, 12,16, 17, and 19 express the transgene (Fig. $4 C$ ), and that levels of immunoreactive CAST protein were 15, 17, 14, 9, and sevenfold higher, respectively, than the levels in Ntg mice (Fig. $4 D$, top). In all of these transgenic lines, hCAST was highly expressed in neuronal tissues including brain, optic nerve, spinal cord and sciatic nerve, but was not detected in peripheral tissues, i.e., kidney, liver, heart or skeletal muscle (data not shown). Heat-stable extracts of brain containing CAST from hCAST mice inhibited calpain II activity in a dose-dependent manner (Fig. 4D, bottom).

Double immunofluorescence labeling of tissue sections from hCAST mice using antibodies to CAST and microtubuleassociated protein 2 (MAP-2) (Fig. $4 E$ ) or glial fibrillary acidic protein (GFAP) (Fig. $4 F$ ) showed that hCAST was localized to neuronal soma and dendrites (Fig. $4 E$ ) but was absent in GFAPpositive astrocytes (Fig. $4 F$ ). 

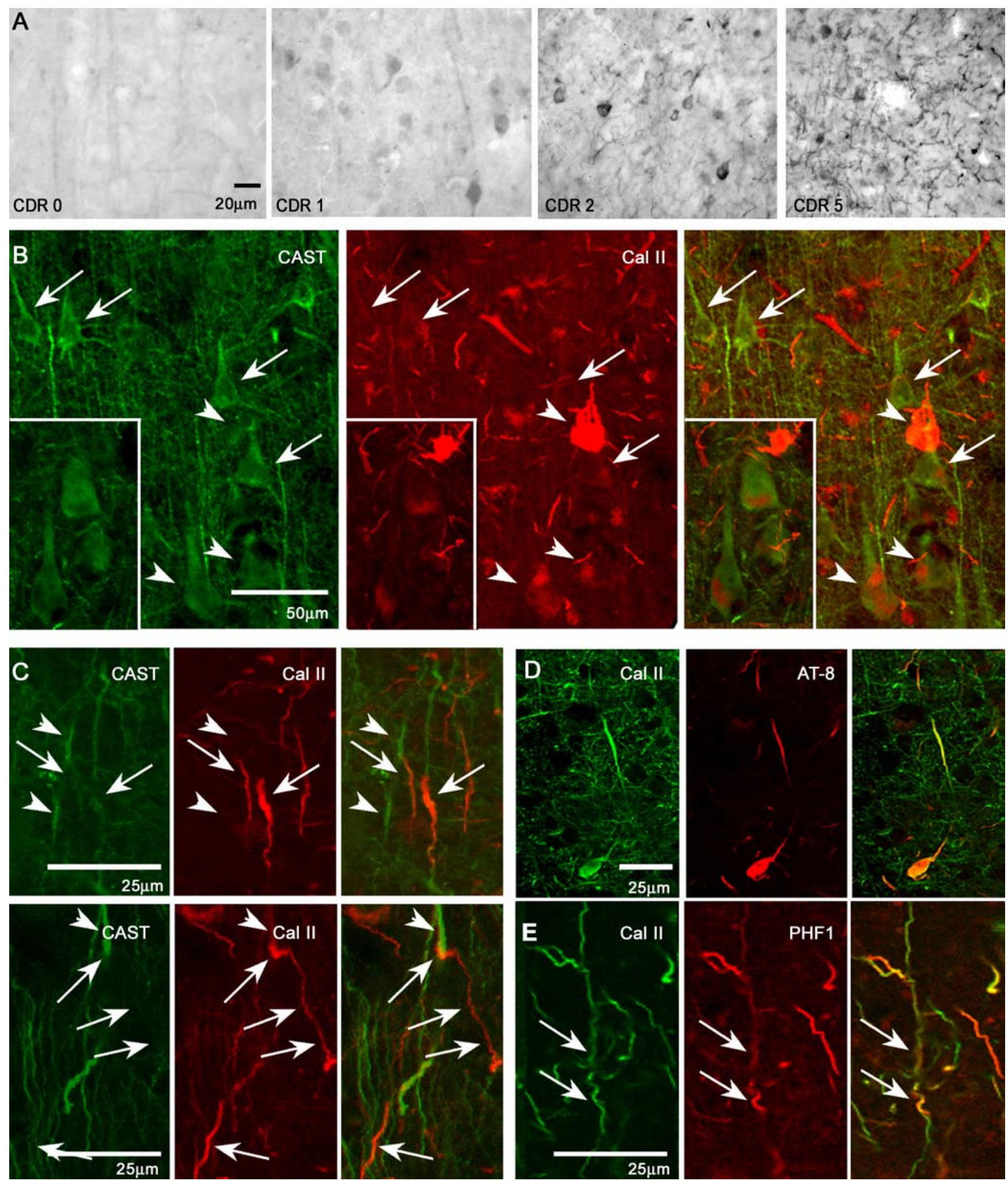

Figure 2. CAST depletion is associated with calpain activation and tau hyperphosphorylation in AD brain. A, Brain sections from AD patients with CDR scores ranging from 0 to 5 immunolabeled with C-18 antibody directed against the active form of Cal II exhibited a qualitative increase in immunostaining that correlated with the magnitude of the CDR score. $B-E$, Double immunolabeling of representative early (Braak stage III) (C-E) and moderate-severe stage AD brains (Braak stage V) (B) immunofluorescence with CAST (I-2-7), and C-18 shows an inverse relationship between CAST and activated Cal II immunoreactivities (C). In early stage AD cases, colocalization of activated Cal II ( $(-18)$ and phosphorylated tau antibodies AT-8 (D) or PHF-1 (E) was prominent, particularly within dystrophic neurites.

Our immunoblot analysis of brain extracts from hCAST and Ntg mice revealed that two well established calpain substrates, $\alpha$-spectrin (Fig. $4 H, S$ ), and MAP-2 (Fig. $4 I, S$ ) were $\sim 2$-fold more abundant in hCAST Tg than in Ntg mice. Interestingly, Cal
I and Cal II levels also were elevated 1.4-fold $(p<0.03)$ and 2.5 -fold $(p<0.05$ ), respectively, in hCAST mice (Fig. $4 J, K, S$ ), suggesting that CAST overexpression slows calpain degradation in vivo. Levels of phospho-ERK (p-ERK), the activated form of 

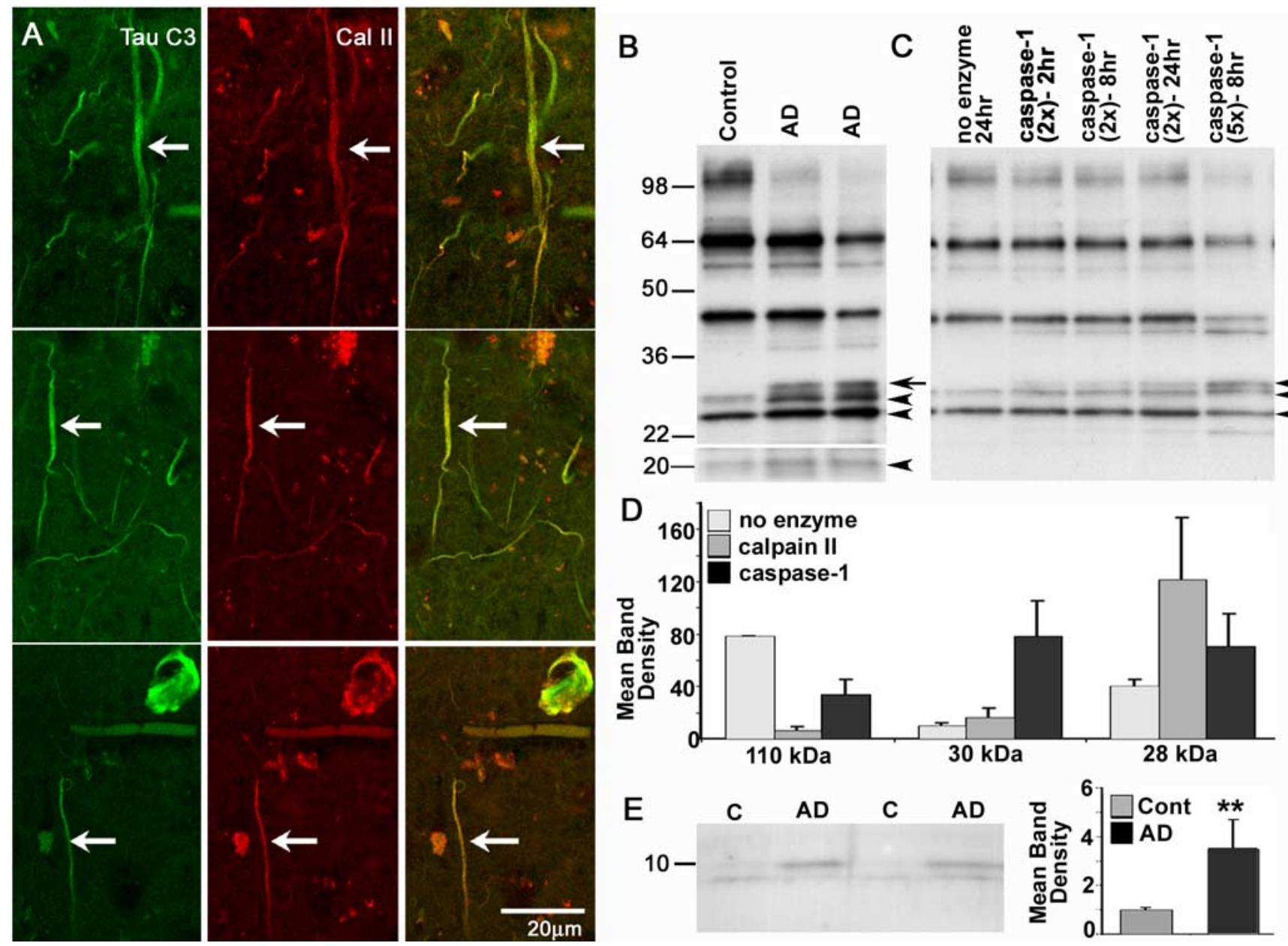

Figure 3. Caspase-calpain/calpastatin interactions in AD brain. A, Double immunolabeling using the antibodies TauC 3 and C-18 revealed significant colocalization between caspase-3 cleaved tau and activated Cal II in AD brains. B. Western blot analysis of heat stable extracts of PFC from control and AD brains probed with CAST antibodies identified increased levels of 30 (arrows), 28 , and 25 , and $20 \mathrm{kDa}$ (arrowheads) CAST immunoreactive bands in AD brains compared with age-matched controls (B) concomitantly with reduced levels of CAST holoprotein. $\boldsymbol{C}$, Heat-stable CAST incubated with caspase-1 in vitro shows a time- and concentration-dependent generation of the $30 \mathrm{kDa}$ fragment $(\boldsymbol{C}$, arrow) but not the 25 or $20 \mathrm{kDa}$ fragments $(\boldsymbol{C}$, arrowheads). $\boldsymbol{D}$, Calpain II digestion produced the 28,25 , and $20 \mathrm{kDa}$ fragments but not the one at $30 \mathrm{kDa}$. E, Activated caspase-1, detected as the $10 \mathrm{kDa}$ active subunit by Western blot, was increased in total extracts from AD brains compared with controls $\left({ }^{* *} p<0.01\right)$.

the kinase, were modestly decreased $(25 \%, p<0.05)$, consistent with its regulation by calpain (Veeranna et al., 2004) (Fig. 4N,S). In contrast, several relatively poor calpain substrates, such as $\alpha$-tubulin (Fig. $4 L, S$ ), total ERK1/2 (Fig. $4 M$ ), and Cdk5 (Fig. 4O) (Pareek et al., 2006) were unaltered in hCAST compared with Ntg mice. Moreover, the levels of activated form of GSK3 $\beta$ (pY216) (Fig. 4Q,S), the inactive form of GSK3 $\beta$ (pSer9) (data not shown) and total GSK3 $\beta$ (Fig. $4 P, S$ ) were not significantly altered by hCAST overexpression. In contrast, the cdk 5 activator protein p35, which is a substrate for calpain (Kusakawa et al., 2000; Lee et al., 2000), was increased in the brains of hCAST mice (Fig. $4 R, S$ ).

\section{Calpastatin overexpression blocks kainic acid induced neurodegeneration in vivo}

Excitotoxicity is one of several mechanisms thought to be involved in neurodegeneration associated with $\mathrm{AD}$ (Louzada et al., 2004). To investigate the role of CAST in neuroprotection against calcium-induced injury in vivo, we injected KA $(0.1 \mathrm{nmol})$ or phosphate buffered saline (PBS) into the hippocampi of hCAST and Ntg mice (Wang et al., 2005). KA promotes neuronal depolarization by binding to the non-NMDA glutamate receptors
GluR5-7 and KA1-KA2, to induce calcium influx and calpain activation leading to seizures, neurodegeneration, and neuronal cell death (Siman et al., 1989; Xu et al., 2007). Neuronal degeneration after direct injection of KA is not dependent on seizure activity (Zaczek et al., 1981; French et al., 1982). Neither control nor hCAST Tg mice injected with PBS displayed observable seizures, whereas control mice injected with KA displayed seizures for $2 \mathrm{~h}$ after KA injection, each lasting for $\sim 60 \mathrm{~s}$ at $3 \mathrm{~min}$ intervals. hCAST mice that received KA remained stationary in one corner during the $2 \mathrm{~h}$ time period but overt seizures were not evident in these mice for a $24 \mathrm{~h}$ time period. Seven days after injection, we performed immunocytochemistry on KA and PBS-treated brain tissue from hCAST and Ntg mice using antibodies directed against the active site region of Cal II (C-24) (Fig. 5A-D), the calpain-cleaved $150 \mathrm{kDa}$ product of $\alpha$-spectrin (Fig. $5 E-H$ ), p-ERK (Fig. 5I-L), NeuN (Fig. 5M-P), and GFAP (Fig. 5Q-T). Cal II immunolabeling was negligible in the hippocampi of PBStreated hCAST and Ntg mice (Fig. 5A,C). An intense C-24 immunoreactivity reflecting Cal II activation was detected within groups of CA1 pyramids in Ntg mice that received KA injections (Fig. 5B). In contrast to KA-treated Ntg mice, Cal II immunoreactivity was dramatically reduced in pyramidal neurons through- 
out the CA1 region of the hippocampus from KA-injected hCAST mice (Fig. 5D). We also found that KA administration to Ntg mice promoted increased immunolabeling of $\alpha$-spectrin cleavage products in CA1 pyramids (Fig. $5 F$ ), compared with PBS treated animals (Fig. 5E,G), whereas KA-treated hCAST mice exhibited reduced levels of immunoreactivity (Fig. $5 H$ ). In Ntg mice receiving KA, phosphoERK immunoreactivity was elevated (Fig. $5 J)$ compared with that of PBS treated mice (Fig. $5 I, K$ ) but in KA-treated hCAST mice, CA1 neurons exhibited decreased immunoreactivity against p-ERK (Fig. 5L).

Immunocytochemistry using an antibody to the neuronal marker NeuN revealed a qualitative decrease in the number of CA1 pyramids in the hippocampus of KA-treated Ntg mice (Fig. $5 \mathrm{~N}$ ) compared with PBS-treated mice (Fig. 5M). Similarly, hCAST mice treated with KA displayed reduced numbers of NeuN-positive CA1 neurons (Fig. 5P) compared with PBS treated mice (Fig. 5O), but this decrease was less dramatic than that seen in KAtreated Ntg animals. As expected, KA treatment to Ntg mice produced a significant increase in the number of GFAPpositive astrocytes (Fig. 5R) in the hippocampus compared with PBS-treated Ntg animals (Fig. 5Q). The magnitude of gliosis was less prominent in hCAST mice receiving PBS (Fig. 5S) or KA (Fig. 5T) compared with Ntg mice treated with KA (Fig. 5R).

We next confirmed by Western blot analyses (Fig. 6) the immunocytochemical findings observed in the brains of hCAST and Ntg mice after KA administration. KA treatment in Ntg mice significantly reduced the levels of endogenous immunoreactive CAST (Fig. 6A), MAP-2 (Fig. $6 C$ ) and $\alpha$-spectrin holoprotein (Fig. $6 D, P$ ), and increased levels of $150 \mathrm{kDa} \alpha$-spectrin breakdown products (Fig. $6 E$ ) relative to $\beta$-tubulin (Fig. 6I). These changes were substantially reduced by the overexpression of hCAST in the transgenic mice. As expected, we found that KA treatment significantly elevated the levels of calpain-activated p-ERK (Fig. 6F,Q) relative to total ERK1/2 levels (Fig. 6G) and RT-97 (Fig. 6S), a phospho-epitope on NF-M regulated in part by ERK 1/2 (Rao et al., 2002), in the brains of Ntg but not in hCAST mice. KA treatment also increased the levels of immunoreactive caspase-3cleaved tau (Fig. $6 H, R$ ). The increase in cleaved tau was significantly attenuated $(p<0.05)$ in KA-treated hCAST mice, indicating that caspase- 3 activation in KA-treated Ntg mice may be a consequence of calpain activation. In contrast, levels of activated caspase-1 were unaltered by KA treatment (data not shown) indicating its activation in $\mathrm{AD}$ brain (Fig. 3) may be upstream of calpain activation.

Because KA neurotoxicity is accompanied by ERK activation and could influence cell survival (Jeon et al., 2000) in part
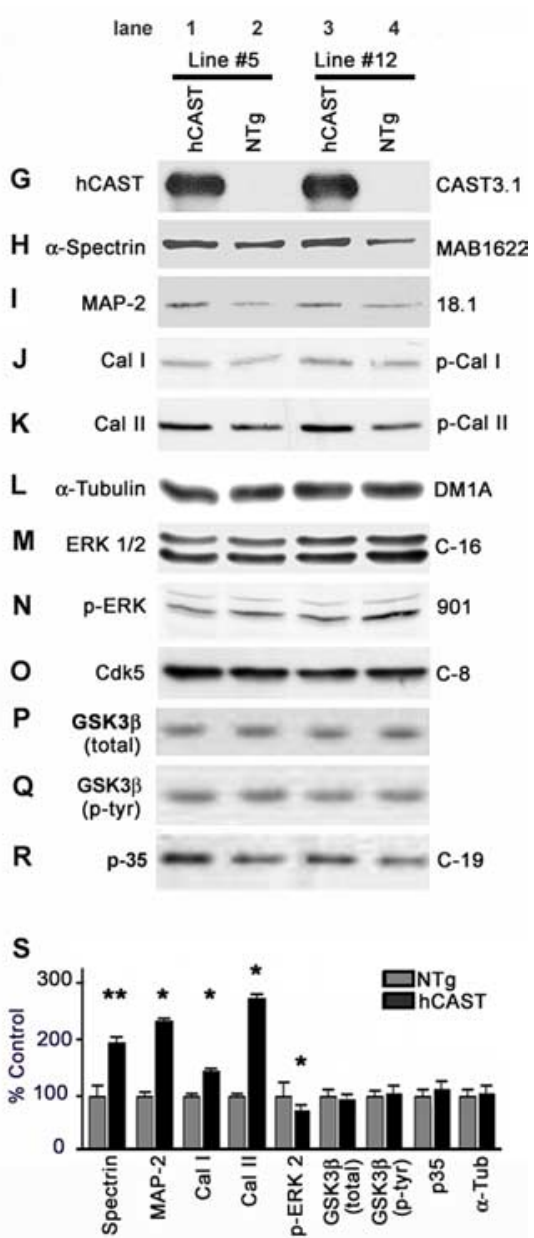

Figure 4. hCAST overexpression in transgenic mice inhibits basal calpain activity. $\boldsymbol{A}$, Schematic representation of Thy1.1-hCAST 3-kb hCAST fragment. C, Western blot analysis of brain extracts of Tg lines probed with CAST (I-2-7 and 3.1) antibodies confirm the presence of hCAST in these lines and the levels of CAST relative to levels of the low molecular weight form of neurofilaments (NF-L; staining (C, bottom). D, Densitometric analysis of the blots with I-2-7 antibody reveal that hCAST is expressed $\sim 15$-fold higher 作 列 stracts from non-transgenic (Ntg) mice (lanes 2,4) and transgenic lines 5 (lane 1) and 12 (lane 3 ) indicate panels $\boldsymbol{H}-\boldsymbol{R}\left(n=7-8\right.$ each, ${ }^{*} p<0.05$; $\left.{ }^{* *} p<0.001\right)$.

through changes in tau phosphorylation (Crespo-Biel et al., 2007), we tested whether KA-induced ERK activation increases tau phosphorylation. Total tau levels detected with T46 (Lee et al., 1991) were unchanged by KA treatment but were significantly higher at baseline in hCAST mice compared with Ntg mice (Fig. $6 J, T)$, a change consistent with a role for calpain in tau turnover in vivo. The AT8 and PHF1 phosphoepitopes on tau known to be generated by ERK1/2, however, were disproportionately increased relative to total tau after KA treatment in Ntg mice (Fig. $6 K, L, U, V$, lane 2). This KA-induced increase in tau phosphorylation was substantially blocked in hCAST mice (Fig. $6 K, L, U, V$, lane 4). Although Cdk5 is capable of phosphorylating the same epitopes on tau, the levels of Cdk5 and p35 were not significantly changed in control or in hCAST mice treated with PBS or KA (Fig. 6M,N). The levels of p25, however, were modestly reduced in control mice treated with $\mathrm{KA}(p<0.0001)$. p25 levels were 

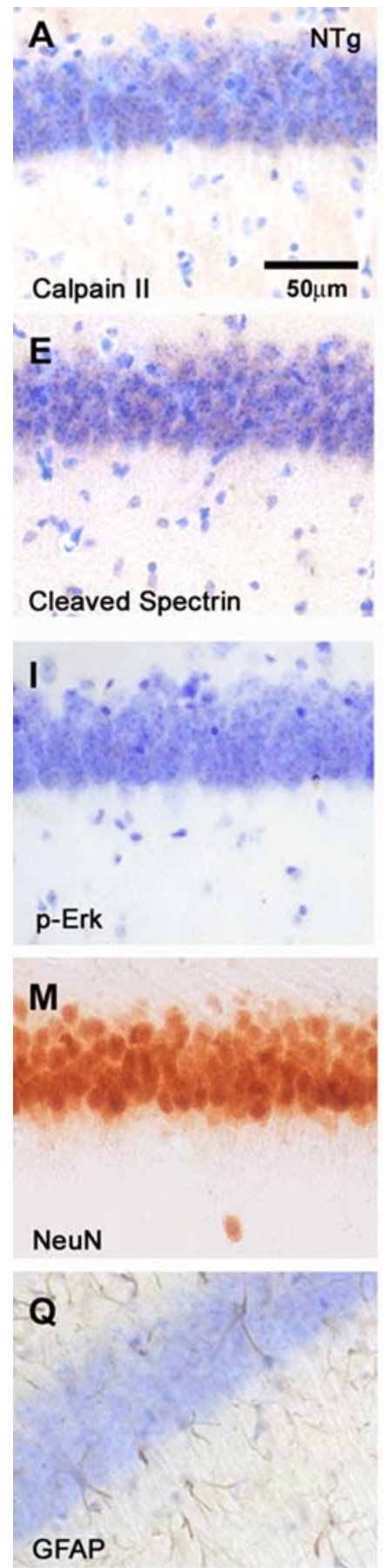
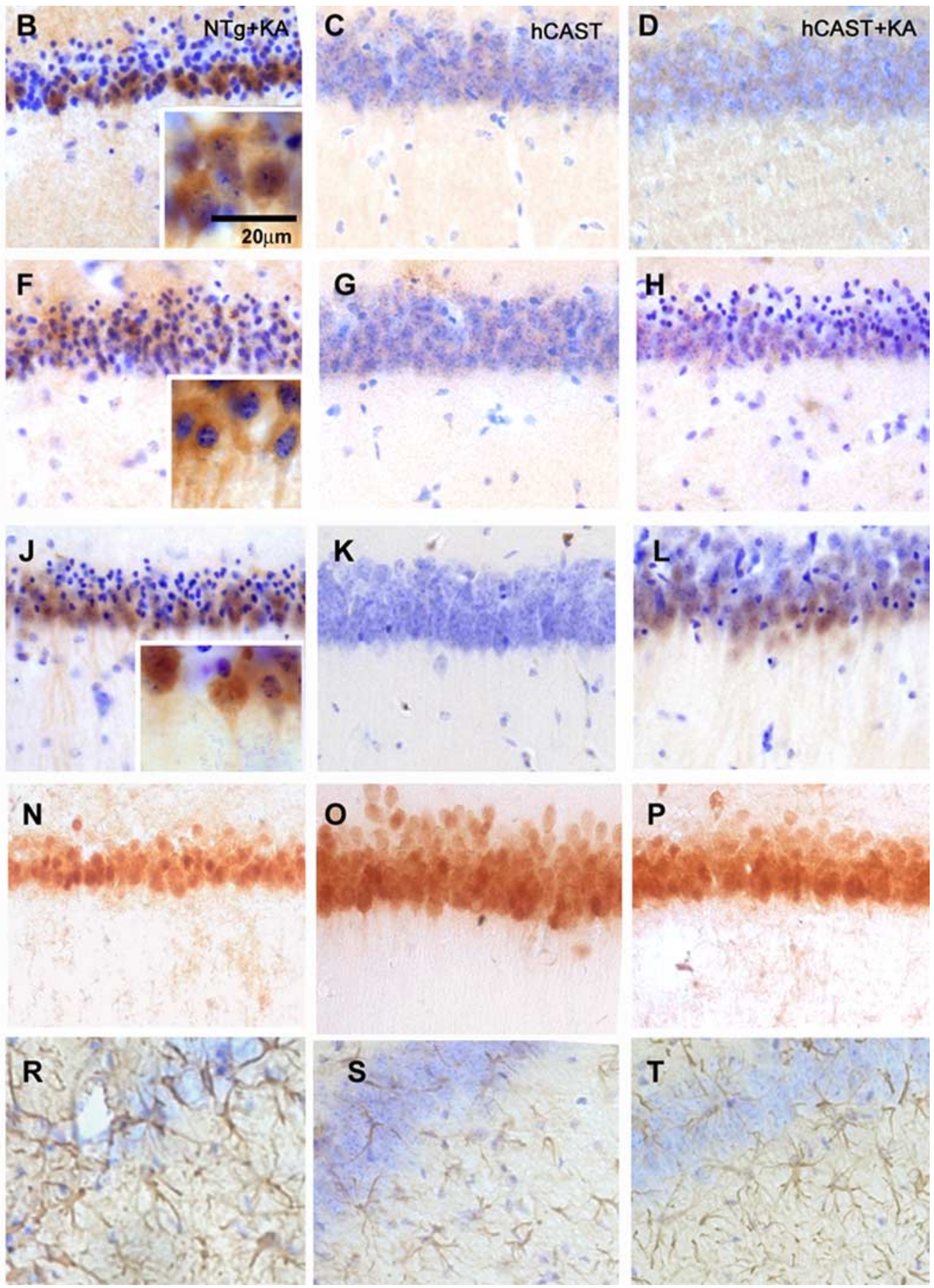

Figure 5. Human CAST overexpression blocks KA induced excitotoxic cell death in mouse CA1 hippocampal neurons. hCAST transgenic $(\boldsymbol{C}, \boldsymbol{G}, \boldsymbol{K}, \mathbf{O}$, and $\boldsymbol{S})$ and their littermate Ntg mice $(\boldsymbol{A}, \boldsymbol{E}, \boldsymbol{I}, \boldsymbol{M}$, and $\mathbf{Q})$ were injected with PBS or PBS containing $0.1 \mathrm{nmol}$ of kainic acid into the hippocampus of $\operatorname{Ntg}(\boldsymbol{B}, \boldsymbol{F}, \boldsymbol{J}, \boldsymbol{N}$ and $\boldsymbol{R})$ or hCAST $(\boldsymbol{D}, \boldsymbol{H}, \boldsymbol{L}, \boldsymbol{P}$, and $\boldsymbol{T})$ and hippocampal sections from the ipsilateral side were taken after $7 \mathrm{~d}$, immunostained with antibodies against activated Cal II $(\boldsymbol{A}-\boldsymbol{D})$, spectrin breakdown products $(\boldsymbol{E}-\boldsymbol{H}), \mathrm{p}$-ERK $(\boldsymbol{I}-\boldsymbol{L})$, Neu N $(\boldsymbol{M}-\boldsymbol{P})$, and GFAP $(\boldsymbol{Q}-\boldsymbol{T})$, and counterstained with cresyl violet ( $n=3-4$ each).

higher in hCAST mice (30\% when compared with NTg; $p<$ $0.044)$ and KA treatment modestly lowered this level (12\%, compared with hCAST alone; $p<0.034$ ) (Fig. 6O). The ratio of p25/p35 modestly decreased in control and hCAST mice treated with KA (Fig. $6 W)(p<0.05)$. We also confirmed a previous finding (Takano et al., 2005) that p25/p35 ratios increase $24 \mathrm{~h}$ after KA administered at a tenfold higher concentration (data not shown) indicating that $\mathrm{p} 35$ and $\mathrm{p} 25$ metabolism shows different patterns depending on the KA neurotoxicity paradigm used. There was no significant change in levels of the activated form of GSK3 $\beta$ (pY216) (supplemental Fig. 2B, available at www. jneurosci.org as supplemental material), inactive form of GSK3 $\beta$ (pSer9) (supplemental Fig. 2A, available at www.jneurosci.org as supplemental material), total GSK3 $\beta$ (supplemental Fig. $2 C, D$, available at www.jneurosci.org as supplemental material), in the ratios of activated to total GSK3 $\beta$ (supplemental Fig. $2 E$, available at www.jneurosci.org as supplemental material) and inactive to total GSK3 $\beta$ (supplemental Fig. $2 F$, available at www. jneurosci.org as supplemental material) in control and hCAST Tg mice treated with PBS or KA. 
CAST depletion by siRNA in neuronal cells accelerates calpain-mediated cell death

To investigate a possible direct role for CAST depletion in promoting calpain activation leading to neurodegeneration, we used RNA interference (RNAi) to lower CAST levels in human SH-SY5Y neuroblastoma cells. A short hairpin RNA ( shRNA) vector was constructed for CAST (shRNA-CAST) and included enhanced green fluorescent protein (eGFP) as an endogenous reporter of shRNA-CAST transfection efficiency. Cells transfected with shRNA-CAST and expressing eGFP exhibited reduced CAST immunoreactivity (Fig. 7A). As a control, we also transfected SH-SY5Y cells with shRNA for carbonic anhydrase (CBR). As expected, cells transfected with shRNA-CBR exhibited reduced CBR immunolabeling but the intensity of CAST immunoreactivity was unaffected (data not shown). We also found that SH-SY5Y cells expressing shRNA-CAST displayed increased immunoreactivity of calpain cleaved spectrin with Ab38 antibody (Zhang et al., 2002) (Fig. $7 B$ ) and caspase-cleaved spectrin with Ab246 antibody (Fig. 7C). Thus, in SH-SY5Y cells, the depletion of CAST appears to promote the activation of calpain leading to caspase activation.

Last, to examine the effect of CAST depletion on calcium induced cell injury, we generated a mixed population of SH-SY5Y cells that were positive or negative for shRNA-CAST as determined by eGFP expression. Cultures were grown in the absence (Fig. $7 D$, control) or presence (Fig. $7 E$ ) of $\mathrm{Ca}^{2+}$ (5 mM) for $2 \mathrm{~h}$. We quantified the proportions of untransfected and CAST-depleted (eGFP-positive) cells lost in the presence or absence of supplemental $\mathrm{Ca}^{2+}$ by counting numbers of DAPIstained and eGFP-positive cells. Untransfected cells (Fig. 7F, bars 1 and 2) were not significantly lost with $\mathrm{Ca}^{2+}$ treatment (Fig. 7F, bars 1 and 2). shRNA-CAST transfection alone did not lower cell numbers (Fig. 7F, bar 3), but $\mathrm{Ca}^{2+}$ treatment resulted in a $40 \%$ reduction in the number of shRNA-CAST transfected cells $(p<0.001)$ (Fig. 7F, bar 4). We found that the calpain inhibitor, calpeptin $(20 \mu \mathrm{M})$, prevented cell death (data not shown) suggesting that cell vulnerability to calcium was mediated by calpain activation.

\section{Discussion}

Our findings show for the first time that CAST is markedly depleted in $\mathrm{AD}$ brain compared with normal controls and that this depletion involves the activation of at least two proteolytic systems, caspases (caspase-1 and -3) and calpains. Using AD brain,

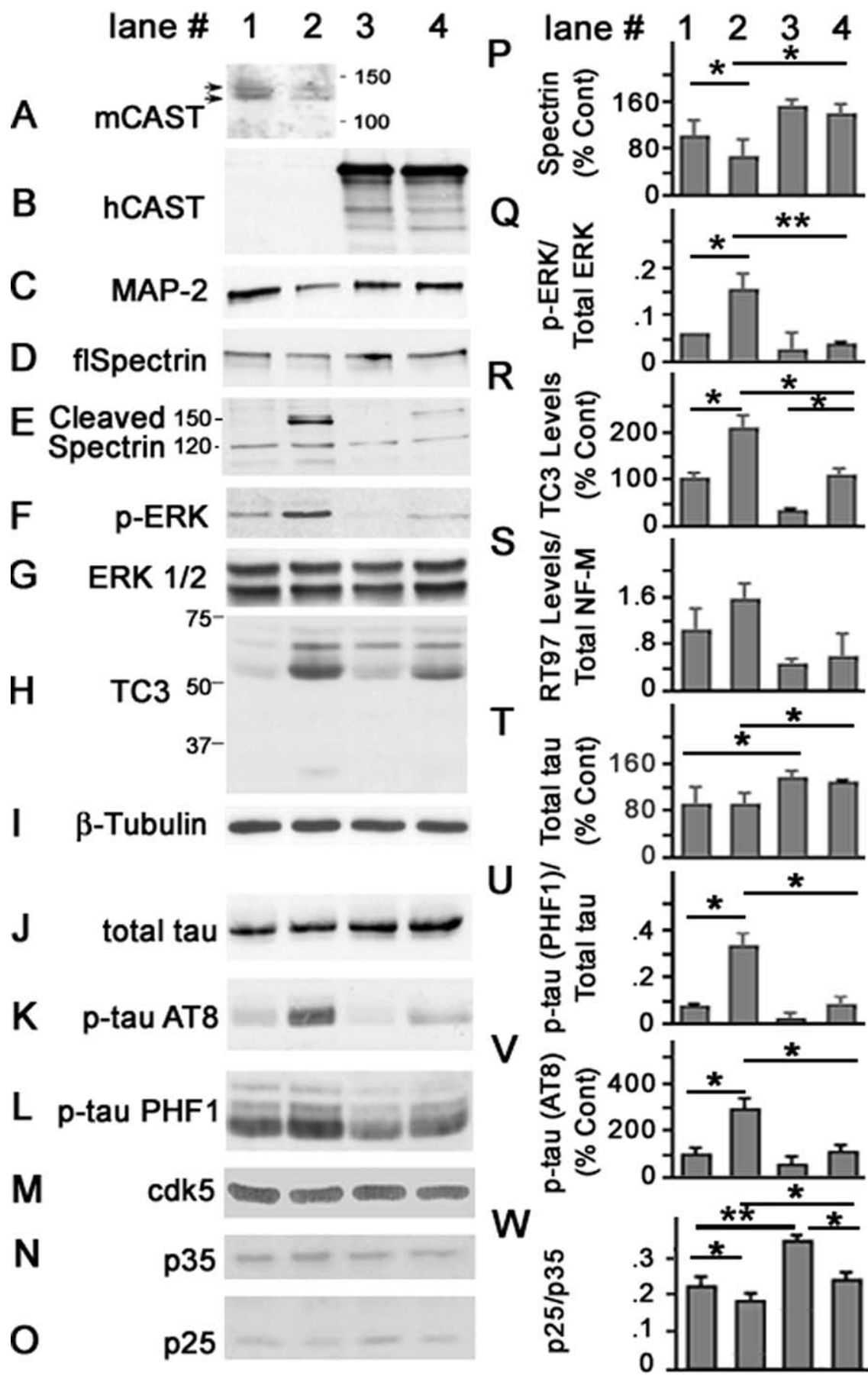

Figure 6. CAST overexpression prevents calpain-mediated ERK activation and cytoskeletal protein degradation in KA-treated mice. Equal amounts of hippocampal extracts from Ntg (lane 1), Ntg + kainic acid (lane 2), hCAST (lane 3), hCAST + kainic acid (lane 4) treated mice (as indicated in Fig. 5) were immunoblotted with 1-2-7 to detect mCAST in Ntg mice $(\boldsymbol{A})$ and with CAST 3.1 againsthCAST $(\boldsymbol{B})$, MAP-2 $(\boldsymbol{C})$, full-length $(\boldsymbol{D})$ and cleaved spectrin $(\boldsymbol{E}), \mathrm{p}$-ERK $(\boldsymbol{F})$, total ERK1/2 $(\boldsymbol{G})$, TauC3 $(\boldsymbol{H}), \boldsymbol{\beta}$-tubulin $(\boldsymbol{I})$, total Tau $(\boldsymbol{J})$, p-Tau (K, AT8), p-Tau (L, PHF1), Cdk5 $(\boldsymbol{M})$, and p35/p25 $(\boldsymbol{N}, \mathbf{O})$ antibodies. Densitometry of spectrin $(\boldsymbol{P}), \mathrm{p}$-ERK/total $\operatorname{ERK1/2}(\boldsymbol{Q})$, TauC3 (R), p-NF-M/total NF-M (S), total Tau $(\boldsymbol{T})$, p-Tau/total tau (U, PHF1), p-Tau (V, AT8), and p25/p35 (W). $(n=5$ each; $\left.{ }^{*} p<0.05,{ }^{* *} p<0.003\right)$.

transgenic mice and cell models, we provide novel evidence that CAST depletion can act upstream of calpains to activate a calpain-dependent cascade of protein kinase activation, cytoskeletal protein hyperphosphorylation, cytoskeletal proteolysis and neurodegeneration (Fig. 8). CAST acts as a buffering mechanism against unwanted collateral protein cleavage during calpain activation (Goll et al., 2003) and it has been proposed that CAST negatively regulates calpain only under pathological conditions 

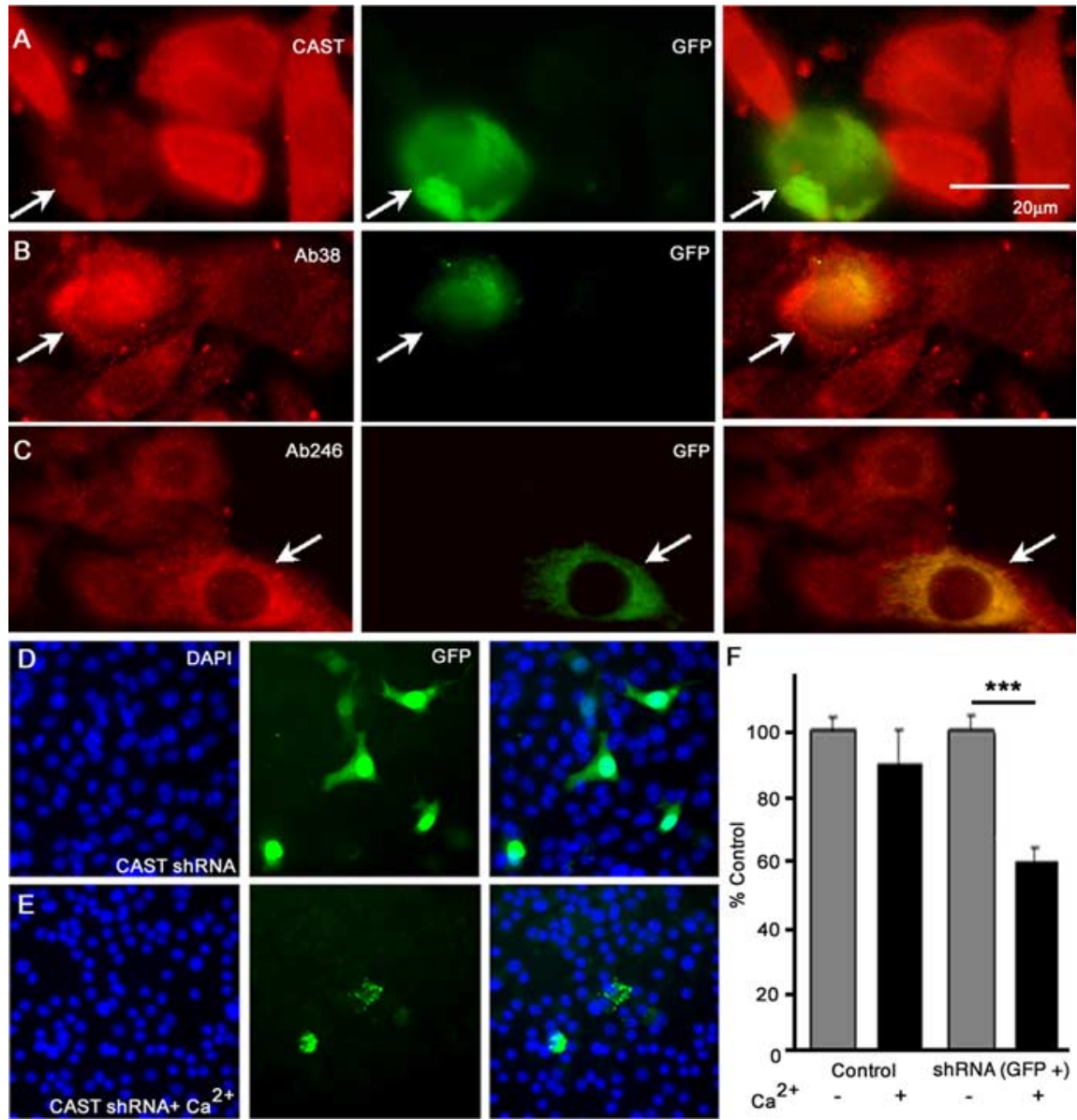

Figure 7. CAST depletion by shRNA activates calpain and caspase-3 and increases vulnerability to calcium-induced cell death in SH-SY5Y cells. SH-SY5Y neuroblastoma cells were transfected with CAST-shRNA vector containing a GFP reporter $(\boldsymbol{A}-\boldsymbol{C})$, displaying significantly reduced levels of CAST relative to non-transfected cells, when cells were immunostained with anti-CAST antibody ( $\boldsymbol{A}$, arrow: GFP positive cell). CAST-depleted cells have increased calpain-specific spectrin breakdown products (Ab38; $\boldsymbol{B})$ and caspase-3-specific spectrin breakdown products (Ab246; $\boldsymbol{C}$. Under conditions of exogenous calcium exposure (E), CASTdepleted (GFP-positive) cells were disproportionately reduced in number relative to the total population of cells stained with DAPI, representing the control cell population $(\boldsymbol{D})$. The graph represents relative proportions of GFP and DAPI-positive cells under conditions with and without calcium-treatment $(\boldsymbol{F})$. Data are expressed as percentage of minus calcium control condition $(\boldsymbol{F})(n=5) .{ }^{* * *} p<0.001$.

(Takano et al., 2005). Our findings provide the first evidence, to our knowledge, that CAST can modulate constitutive calpain activity in vivo. CAST overexpression in neurons significantly elevated the steady-state levels of well known calpain substrates, including tau and p35, the activator protein of Cdk5 that phosphorylates tau, establishing for the first time a role for calpain in tau turnover in vivo. CAST overexpression also raised levels of Cal I and II, indicating that the turnover of calpain is regulated in part by its endogenous inhibitor. Furthermore, selectively lowering CAST levels in cells with shRNA treatment increased the levels of calpain activation without inducing acute cell death. These results accord with observations that CAST interacts with calpains at physiological calcium levels (Melloni et al., 2006). Supporting a role for CAST in tonically regulating calpain activity are additional studies showing that a transient decline of CAST during myogenin-induced muscle differentiation activates calpain to levels required for myoblast fusion and differentiation (Barnoy and Kosower, 2007). Similar regulation of calpain activation by CAST is also required during PC12 differentiation (Vaisid et al., 2005).

Whether as a buffer or a tonic regulator of calpain activity, CAST exerted a significant neuroprotection against neurotoxic- ity in our studies. Higher CAST levels substantially prevented KA-induced cytoskeletal protein disruption, ERK activation, neurodegeneration and associated reactive gliosis. Interestingly, higher CAST levels blocked overt seizure activity at the tested dose of KA, raising the possibility that calpain activation is involved in the mechanism underlying seizure generation after intrahippocampal KA administration. In this regard, hippocampal seizure activity and seizure behavior are significantly more frequent in individuals with AD (Hesdorffer et al., 1996; Mendez and Lim, 2003; Amatniek et al., 2006). Protection against neurodegeneration by CAST is not related directly to seizure suppression, because seizure generation is not required for neurodegeneration in this paradigm (Zaczek et al., 1981; French et al., 1982).

Although total CAST levels were most strikingly depleted at later stages of $\mathrm{AD}$ when neuron loss is extensive, CAST disappeared focally along segments of dystrophic and atrophic neurites at early stages of $\mathrm{AD}$, indicating a link between progressive CAST depletion and neurofibrillary neurodegeneration. These findings confirm one previous study of calpain inhibitory activity showing a decline within a group of AD brains as severity of neuropathology increased (Nilsson et al., 1990); however, our study establishes for the first time that CAST is depleted in AD brain compared with levels in normal controls. As a suicide substrate of calpains, CAST is most likely to be continuously turned over, in part, attributable to persistent calpain hyperactivation, which begins early in AD (Saito et al., 1993) in response to calcium dysregulation caused by AD risk factors, including A $\beta$ toxicity (Fifre et al., 2006), oxidative stress (Ishihara et al., 2000), excitotoxicity (Xu et al., 2007), and presenilin mutations (Siman et al., 2000). In addition to calpains, however, caspases are also upregulated in neurons in $\mathrm{AD}$ (Matsui et al., 2006), particularly at the later disease stages when CAST-inhibitory activity is observed to decline most markedly. Caspases, particularly caspase-1, cleave CAST into inactive fragments (Wang et al., 1998), unlike calpains which cleave CAST into smaller polypeptides that retain some inhibitory activity. We demonstrated that caspase- 1 is abnormally activated in $\mathrm{AD}$ brain (Fig. $3 B, C, E)(\mathrm{Zhu}$ et al., 1999), degrades hCAST holoprotein, and generates a specific CAST fragment, which was found in AD brain at significantly elevated levels. Interestingly, caspase-1 regulates CAST levels during PC12 cell and myoblast differentiation (Vaisid et al., 2005). These results support an interplay between the calpain and caspase proteolytic systems in neurofibrillary degeneration. In further support of this cross-talk, we observed that caspase-3, another caspase capable of degrading CAST holoprotein, is activated focally along neurites in the same locations where CAST is depleted. This finding accords with data that other caspasecleaved proteins are also located in dystrophic neurites (Ayala- 
Grosso et al., 2006). The further observation that caspase 3-cleaved tau, but not activated caspase-1, increased in KA treated control but not in hCAST mice suggests that activation of caspase- 3 , but not of caspase-1, is downstream of calpain activation in neurotoxicity. These proteases, and possibly others, lower CAST to levels that could elevate constitutive calpain activity and increase the vulnerability of neurons to cytoskeleton disruption and cell death under conditions of calcium injury.

CAST depletion and calpain activation along dystrophic neurites coinciding with ERK1/2 activation and tau/neurofilament phosphorylation supports a close interrelationship among these events. This was further established in our studies of KAmediated neurotoxicity. Cal II, which is activated as CAST is depleted from neurites, has been shown to be recruited to intraneuronal tau aggregates in $\mathrm{AD}$ brain (Adamec et al., 2002), and may be related to the tau truncations proposed to promote tau aggregation (Gamblin et al., 2003). Calpains activate signaling cascades mediated by Cdk5, ERK1/2, GSK3, PKC, and calcineurin, thereby regulating the phosphorylation states and functions of cytoskeletal proteins, including neurofilament subunits and tau (Shiurba et al., 1996; Lee et al., 2000; Lee and Tsai, 2003; Veeranna et al., 2004; Amadoro et al., 2006; Plattner et al., 2006). Calpain-mediated Cdk5 activation has been previously linked to tau hyperphosphorylation, and neurodegeneration in AD (Lee et al., 2000; Patrick et al., 1999; Taniguchi et al., 2001; Cruz et al., 2003; Lee and Tsai, 2003) and excitotoxic states (Crespo-Biel et al., 2007). We did not observe an increase in p35 conversion to p25 in Western blot analyses of AD brains, consistent with data from other labs (Tandon et al., 2003; Yoo and Lubec 2001; Taniguchi et al., 2001; Takashima et al., 2001; Cole et al., 2007). In our KA neurotoxicity paradigm, we did not see an increase in p 35 conversion to p 25 or p25/p35 ratio at a $0.1 \mathrm{nmol}$ concentration of KA in control mice, although we have confirmed the higher p25/p35 ratios observed in mice by Takano et al. (2005) using higher KA doses for shorter periods (M. V. Rao, unpublished data). Although GSK $3 \beta$ activation has been implicated in amyloid-mediated events leading to cytoskeletal protein hyperphosphorylation in AD (Hooper et al., 2008), we observed no changes in distribution or abundance of active, inactive or total GSK3 $\beta$. Less attention has been paid to a possible role of ERK in AD and our findings strongly support a role for calpain-mediated ERK activation in the hyperphosphorylation of neurofilament proteins and tau seen in AD brain, which is known to be dependent on MEK 1/2, the upstream regulator of ERK 1/2 (Veeranna et al., 2004). The reversal of these phosphorylation events in vivo by hCAST supports the neuroprotective role of CAST and the importance of gradual CAST depletion by caspases and calpains as a trigger for calpain-mediated cascades leading to neurodegeneration (Fig. 8).

We observed that lowering CAST levels by shRNA elevates constitutive calpain activity and sensitizes neuronal cells to calpain-mediated cell death after calcium injury. These results indicate that CAST depletion, mediated by caspases or other pro-
CAST transcription

CAST dephosphorylation

Activated caspase- 1,3

Other proteases

$\downarrow$

CAST Depletion

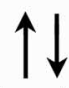

Calpain activation

\section{BI)}

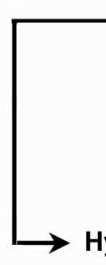

ERK $1 / 2$ activation

Other kinases<smiles>[CH]1[CH]CC1</smiles>

Tau, NF, MAP2

Hyperphosphorylation

Cleavage

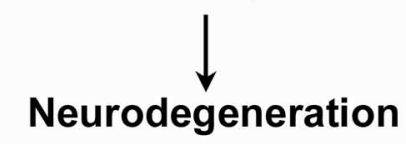

Caspase-3 activation

BID/p53 cleavage

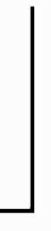

Figure 8. Schematic highlighting CAST depletion as both an upstream and downstream event in calpain activation and calpain-mediated cytoskeleton hyperphosphorylation and proteolysis leading to neurodegeneration in AD. The schematic illustrates the cross-talk between the calpain and caspase proteolytic systems in AD shown in this study. Other proposed influences on CAST levels and inhibitory functions that may promote calpain activation are also indicated.

teases, can be a cause of calpain overactivation rather than simply its consequence (Fig. 8). Supporting this possibility are data showing that the naturally high CAST levels in juvenile rodents compared with mature rats correlate with greater resistance of the young rats to calpain-mediated neuronal cell death (Wingrave et al., 2004). Conversely, pathological decreases in CAST mRNA expression during sepsis activate calpains (Wei et al., 2005). Aging-related declines in CAST have also been linked to pathologic changes in some tissues (Nilsson et al., 1990; Averna et al., 2001). In addition, preventing CAST decline because of caspase activation has cytoprotective effects in embolic cerebral ischemia (Han et al., 2006) and renal ischemia-reperfusion injury (Shi et al., 2000).

Synthetic calpain inhibitors have been shown to be neuroprotective under certain injury conditions, but this neuroprotection is inconsistent or incomplete in many cases. The calpain inhibitors used in previous studies, however, can inhibit other cysteine proteases, including cathepsins that may have anti or proapoptotic effects and other effects on cell survival in different injury paradigms (Carragher, 2006). Multiple proteolytic systems are often activated in pathologic states, as illustrated by our observations that caspases can become activated in some settings of calpain activation, and they can promote further calpain activation by degrading CAST (Fig. 8). These findings suggest that neuroprotective regimens may need to target multiple proteolytic systems selectively while avoiding effects on proteolytic systems that confer protection.

\section{References}

Adamec E, Mohan P, Vonsattel JP, Nixon RA (2002) Calpain activation in neurodegenerative diseases: confocal immunofluorescence study with antibodies specifically recognizing the active form of calpain 2. Acta Neuropathol (Berl) 104:92-104.

Amadoro G, Ciotti MT, Costanzi M, Cestari V, Calissano P, Canu N (2006) NMDA receptor mediates tau-induced neurotoxicity by calpain and ERK/MAPK activation. Proc Natl Acad Sci U S A 103:2892-2897. 
Amatniek JC, Hauser WA, DelCastillo-Castaneda C, Jacobs DM, Marder K, Bell K, Albert M, Brandt J, Stern Y (2006) Incidence and predictors of seizures in patients with Alzheimer's disease. Epilepsia 47:867-872.

Averna M, De Tullio R, Salamino F, Minafra R, Pontremoli S, Melloni E (2001) Age-dependent degradation of calpastatin in kidney of hypertensive rats. J Biol Chem 276:38426-38432.

Ayala-Grosso C, Tam J, Roy S, Xanthoudakis S, Da Costa D, Nicholson DW, Robertson GS (2006) Caspase-3 cleaved spectrin colocalizes with neurofilament-immunoreactive neurons in Alzheimer's disease. Neuroscience 141:863-874.

Barnoy S, Kosower NS (2007) Calpastatin in rat myoblasts: transient diminution and decreased phosphorylation depend on myogenin-directed myoblast differentiation. Int J Biochem Cell Biol 39:253-261.

Bartus RT, Elliott PJ, Hayward NJ, Dean RL, Harbeson S, Straub JA, Li Z, Powers JC (1995) Calpain as a novel target for treating acute neurodegenerative disorders. Neurol Res 17:249-258.

Battaglia F, Trinchese F, Liu S, Walter S, Nixon RA, Arancio O (2003) Calpain inhibitors, a treatment for Alzheimer's disease: position paper. J Mol Neurosci 20:357-362.

Carragher NO (2006) Calpain inhibition: a therapeutic strategy targeting multiple disease states. Curr Pharm Des 12:615-638.

Cataldo AM, Thayer CY, Bird ED, Wheelock TR, Nixon RA (1990) Lysosomal proteinase antigens are prominently localized within senile plaques of Alzheimer's disease: evidence for a neuronal origin. Brain Res 513:181-192.

Cole AR, Noble W, van Aalten L, Plattner F, Meimaridou R, Hogan D, Taylor M, LaFrancois J, Gunn-Moore F, Verkhratsky A, Oddo S, LaFerla F, Giese KP, Dineley KT, Duff K, Richardson JC, Yan SD, Hanger DP, Allan SM, Sutherland C (2007) Collapsin response mediator protein-2 hyperphosphorylation is an early event in Alzheimer's disease progression. J Neurochem 103:1132-1144.

Crespo-Biel N, Canudas AM, Camins A, Pallàs M (2007) Kainate induces AKT, ERK and cdk5/GSK3beta pathway deregulation, phosphorylates tau protein in mouse hippocampus. Neurochem Int 50:435-442.

Cruz JC, Tseng HC, Goldman JA, Shih H, Tsai LH (2003) Aberrant Cdk5 activation by $\mathrm{p} 25$ triggers pathological events leading to neurodegeneration and neurofibrillary tangles. Neuron 40:471-483.

Dottavio-Martin D, Ravel JM (1978) Radiolabeling of proteins by reductive alkylation with [14C] formaldehyde and sodium cyanoborohydride. Anal Biochem 87:562-565.

Fifre A, Sponne I, Koziel V, Kriem B, Yen Potin FT, Bihain BE, Olivier JL, Oster T, Pillot T (2006) Microtubule-associated protein MAP1A, MAP1B, and MAP2 proteolysis during soluble amyloid beta-peptideinduced neuronal apoptosis. Synergistic involvement of calpain and caspase-3. J Biol Chem 281:229-240.

Franklin KBJ, Paxions G (1997) The mouse brain in stereotaxic coordinates. San Diego: Academic.

French ED, Aldinio C, Schwarcz R (1982) Intrahippocampal kainic acid, seizures and local neuronal degeneration: relationships assessed in unanesthetized rats. Neuroscience 7:2525-2536.

Gamblin TC, Chen F, Zambrano A, Abraha A, Lagalwar S, Guillozet AL, Lu M, Fu Y, Garcia-Sierra F, LaPointe N, Miller R, Berry RW, Binder LI, Cryns VL (2003) Caspase cleavage of tau: linking amyloid and neurofibrillary tangles in Alzheimer's disease. Proc Natl Acad Sci U S A 100:10032-10037.

Goll DE, Thompson VF, Taylor RG, Zalewska T (1992) Is calpain activity regulated by membranes and autolysis or by calcium and calpastatin? Bioessays 14:549-556.

Goll DE, Thompson VF, Li H, Wei W, Cong J (2003) The calpain system. Physiol Rev 83:731-801.

Grynspan F, Griffin WB, Mohan PS, Shea TB, Nixon RA (1997a) Calpains and calpastatin in SH-SY5Y neuroblastoma cells during retinoic acidinduced differentiation and neurite outgrowth: comparison with the human brain calpain system. J Neurosci Res 48:181-191.

Grynspan F, Griffin WR, Cataldo A, Katayama S, Nixon RA (1997b) Active site-directed antibodies identify calpain II as an early-appearing and pervasive component of neurofibrillary pathology in Alzheimer's disease. Brain Res 763:145-158.

Han F, Shirasaki Y, Fukunaga K (2006) 3-[2-[4-(3-Chloro-2methylphenylmethyl)-1-piperazinyl ]ethyl]-5,6-dimethoxy -1-(4-imidazolylmethyl)- $1 \mathrm{H}$-indazole dihydro-chloride 3.5 hydrate (DY-9760e) is neuroprotective in rat microsphere embolism: role of the cross-talk be- tween calpain and caspase- 3 through calpastatin. J Pharmacol Exp Ther 317:529-536.

Hesdorffer DC, Hauser WA, Annegers JF, Kokmen E, Rocca WA (1996) Dementia and adult-onset unprovoked seizures. Neurology 46:727-730.

Hitomi K, Yokoyama A, Maki M (1998) Expression of biologically active human calpastatin in baculovirus-infected insect cells and in Escherichia coli. Biosci Biotechnol Biochem 62:136-141.

Hooper C, Killick R, Lovestone S (2008) The GSK3 hypothesis of Alzheimer's disease. J Neurochem 104:1433-1439.

Ishihara I, Minami Y, Nishizaki T, Matsuoka T, Yamamura H (2000) Activation of calpain precedes morphological alterations during hydrogen peroxide-induced apoptosis in neuronally differentiated mouse embryonal carcinoma P19 cell line. Neurosci Lett 279:97-100.

Jeon SH, Kim YS, Bae CD, Park JB (2000) Activation of JNK and p38 in rat hippocampus after kainic acid induced seizure. Exp Mol Med 32:227-230.

Julien JP, Mushynski WE (1998) Neurofilaments in health and disease. Prog Nucleic Acid Res Mol Biol 61:1-23.

Kusakawa G, Saito T, Onuki R, Ishiguro K, Kishimoto T, Hisanaga S (2000) Calpain-dependent proteolytic cleavage of the p35 cyclin-dependent kinase 5 activator to p25. J Biol Chem 275:17166-17172.

Law A, Gauthier S, Quirion R (2001) Neuroprotective and neurorescuing effects of isoform-specific nitric oxide synthase inhibitors, nitric oxide scavenger, and antioxidant against beta-amyloid toxicity. Br J Pharmacol 133:1114-1124.

Lee MS, Tsai LH (2003) Cdk5: one of the links between senile plaques and neurofibrillary tangles? J Alzheimers Dis 5:127-137.

Lee MS, Kwon YT, Li M, Peng J, Friedlander RM, Tsai LH (2000) Neurotoxicity induces cleavage of $\mathrm{p} 35$ to $\mathrm{p} 25$ by calpain. Nature 405:360-364.

Lee VM, Balin BJ, Otvos L Jr, Trojanowski JQ (1991) A68: a major subunit of paired helical filaments and derivatized forms of normal Tau. Science 251:675-678

Louzada PR, Lima AC, Mendonca-Silva DL, Noël F, De Mello FG, Ferreira ST (2004) Taurine prevents the neurotoxicity of beta-amyloid and glutamate receptor agonists: activation of GABA receptors and possible implications for Alzheimer's disease and other neurological disorders. FASEB J 18:511-518.

Matsui T, Ramasamy K, Ingelsson M, Fukumoto H, Conrad C, Frosch MP, Irizarry MC, Yuan J, Hyman BT (2006) Coordinated expression of caspase 8, 3 and 7 mRNA in temporal cortex of Alzheimer disease: relationship to formic acid extractable abeta42 levels. J Neuropathol Exp Neurol 65:508-515.

Melloni E, Averna M, Stifanese R, De Tullio R, Defranchi E, Salamino F, Pontremoli S (2006) Association of calpastatin with inactive calpain: a novel mechanism to control the activation of the protease? J Biol Chem 281:24945-24954.

Mendez M, Lim G (2003) Seizures in elderly patients with dementia: epidemiology and management. Drugs Aging 20:791-803.

Mohan PS, Nixon RA (1995) Purification and properties of high molecular weight calpastatin from bovine brain. J Neurochem 64:859-866.

Nilsson E, Alafuzoff I, Blennow K, Blomgren K, Hall CM, Janson I, Karlsson I, Wallin A, Gottfries CG, Karlsson JO (1990) Calpain and calpastatin in normal and Alzheimer-degenerated human brain tissue. Neurobiol Aging $11: 425-431$.

Nixon RA (2003) The calpains in aging and aging-related diseases. Ageing Res Rev 2:407-418.

Pareek TK, Keller J, Kesavapany S, Pant HC, Iadarola MJ, Brady RO, Kulkarni AB (2006) Cyclin-dependent kinase 5 activity regulates pain signaling. Proc Natl Acad Sci U S A 103:791-796.

Parvathy S, Davies P, Haroutunian V, Purohit DP, Davis KL, Mohs RC, Park H, Moran TM, Chan JY, Buxbaum JD (2001) Correlation between Abetax-40-, Abetax-42-, and Abetax-43-containing amyloid plaques and cognitive decline. Arch Neurol 58:2025-2032.

Patrick GN, Zukerberg L, Nikolic M, de la Monte S, Dikkes P, Tsai LH (1999) Conversion of p35 to p25 deregulates Cdk5 activity and promotes neurodegeneration. Nature 402:615-622.

Plattner F, Angelo M, Giese KP (2006) The roles of cyclin-dependent kinase 5 and glycogen synthase kinase 3 in tau hyperphosphorylation. J Biol Chem 281:25457-25465.

Pompl PN, Yemul S, Xiang Z, Ho L, Haroutunian V, Purohit D, Mohs R, Pasinetti GM (2003) Caspase gene expression in the brain as a function of the clinical progression of Alzheimer disease. Arch Neurol 60:369-376. Rao MV, Garcia ML, Miyazaki Y, Gotow T, Yuan A, Mattina S, Ward CM, 
Calcutt NA, Uchiyama Y, Nixon RA, Cleveland DW (2002) Gene replacement in mice reveals that the heavily phosphorylated tail of neurofilament heavy subunit does not affect axonal caliber or the transit of cargoes in slow axonal transport. J Cell Biol 158:681-693.

Saito K, Elce JS, Hamos JE, Nixon RA (1993) Widespread activation of calcium-activated neutral proteinase (calpain) in the brain in Alzheimer disease: a potential molecular basis for neuronal degeneration. Proc Natl Acad Sci U S A 90:2628-2632.

Schmidt SD, Jiang Y, Nixon RA, Mathews PM (2005) Tissue processing prior to protein analysis and amyloid-beta quantitation. Methods Mol Biol 299:267-278.

Shea TB, Spencer MJ, Beermann ML, Cressman CM, Nixon RA (1996) Calcium influx into human neuroblastoma cells induces ALZ-50 immunoreactivity: involvement of calpain-mediated hydrolysis of protein kinase C. J Neurochem 66:1539-1549.

Shi Y, Melnikov VY, Schrier RW, Edelstein CL (2000) Downregulation of the calpain inhibitor protein calpastatin by caspases during renal ischemia-reperfusion. Am J Physiol Renal Physiol 279:F509-F517.

Shiurba RA, Ishiguro K, Takahashi M, Sato K, Spooner ET, Mercken M, Yoshida R, Wheelock TR, Yanagawa H, Imahori K, Nixon RA (1996) Immunocytochemistry of tau phosphoserine 413 and tau protein kinase I in Alzheimer pathology. Brain Res 737:119-132.

Siman R, Noszek JC, Kegerise C (1989) Calpain I activation is specifically related to excitatory amino acid induction of hippocampal damage. J Neurosci 9:1579-1590.

Siman R, Reaume AG, Savage MJ, Trusko S, Lin YG, Scott RW, Flood DG (2000) Presenilin-1 P264L knock-in mutation: differential effects on abeta production, amyloid deposition, and neuronal vulnerability. J Neurosci 20:8717-8726.

Takano J, Tomioka M, Tsubuki S, Higuchi M, Iwata N, Itohara S, Maki M, Saido TC (2005) Calpain mediates excitotoxic DNA fragmentation via mitochondrial pathways in adult brains: evidence from calpastatin mutant mice. J Biol Chem 280:16175-16184.

Takashima A, Murayama M, Yasutake K, Takahashi H, Yokoyama M, Ishiguro K (2001) Involvement of cyclin dependent kinase5 activator p25 on tau phosphorylation in mouse brain. Neurosci Lett 306:37-40.

Tandon A, Yu H, Wang L, Rogaeva E, Sato C, Chishti MA, Kawarai T, Hasegawa $\mathrm{H}$, Chen F, Davies P, Fraser PE, Westaway D, St George-Hyslop PH (2003) Brain levels of CDK5 activator p25 are not increased in Alzheimer's or other neurodegenerative diseases with neurofibrillary tangles. J Neurochem 86:572-581.

Taniguchi S, Fujita Y, Hayashi S, Kakita A, Takahashi H, Murayama S, Saido TC, Hisanaga S, Iwatsubo T, Hasegawa M (2001) Calpain-mediated degradation of $\mathrm{p} 35$ to $\mathrm{p} 25$ in postmortem human and rat brains. FEBS Lett 489:46-50.

Thornberry NA (1994) Interleukin-1 beta converting enzyme. Methods Enzymol 244:615-631.

Vaisid T, Kosower NS, Barnoy S (2005) Caspase-1 activity is required for neuronal differentiation of PC12 cells: cross-talk between the caspase and calpain systems. Biochim Biophys Acta 1743:223-230.

Veeranna, Kaji T, Boland B, Odrljin T, Mohan P, Basavarajappa BS, Peterhoff C, Cataldo A, Rudnicki A, Amin N, Li BS, Pant HC, Hungund BL, Arancio O, Nixon RA (2004) Calpain mediates calcium-induced activation of the erk1,2 MAPK pathway and cytoskeletal phosphorylation in neurons: relevance to Alzheimer's disease. Am J Pathol 165:795-805.

Vitto A, Nixon RA (1986) Calcium-activated neutral proteinase of human brain: subunit structure and enzymatic properties of multiple molecular forms. J Neurochem 47:1039-1051.

Wang KK, Posmantur R, Nadimpalli R, Nath R, Mohan P, Nixon RA, Talanian RV, Keegan M, Herzog L, Allen H (1998) Caspase-mediated fragmentation of calpain inhibitor protein calpastatin during apoptosis. Arch Biochem Biophys 356:187-196.

Wang Q, Yu S, Simonyi A, Sun GY, Sun AY (2005) Kainic acid-mediated excitotoxicity as a model for neurodegeneration. Mol Neurobiol 31:3-16.

Wei W, Fareed MU, Evenson A, Menconi MJ, Yang H, Petkova V, Hasselgren PO (2005) Sepsis stimulates calpain activity in skeletal muscle by decreasing calpastatin activity but does not activate caspase-3. Am J Physiol Regul Integr Comp Physiol 288:R580-R590.

Wingrave JM, Sribnick EA, Wilford GG, Matzelle DD, Mou JA, Ray SK, Hogan EL, Banik NL (2004) Higher calpastatin levels correlate with resistance to calpain-mediated proteolysis and neuronal apoptosis in juvenile rats after spinal cord injury. J Neurotrauma 21:1240-1254.

Wu HY, Lynch DR (2006) Calpain and synaptic function. Mol Neurobiol 33:215-236.

Xu W, Wong TP, Chery N, Gaertner T, Wang YT, Baudry M (2007) Calpain-mediated mGluR1alpha truncation: a key step in excitotoxicity. Neuron 53:399-412.

Yoo BC, Lubec G (2001) p25 protein in neurodegeneration. Nature 411:763-764.

Zaczek R, Nelson M, Coyle JT (1981) Kainic acid neurotoxicity and seizures. Neuropharmacology 20:183-189.

Zhang C, Siman R, Xu YA, Mills AM, Frederick JR, Neumar RW (2002) Comparison of calpain and caspase activities in the adult rat brain after transient forebrain ischemia. Neurobiol Dis 10:289-305.

Zhu SG, Sheng JG, Jones RA, Brewer MM, Zhou XQ, Mrak RE, Griffin WS (1999) Increased interleukin-1beta converting enzyme expression and activity in Alzheimer disease. J Neuropathol Exp Neurol 58:582-587. 